\title{
Mõned teesid hüvastijätuks mõistega ajalooline muistend
}

Klaus Graf

Ajalool ise muistendi, nagu ka rahvaraamatu mõiste (vt ka Müller 1985) määratlemine oli romantismi ajal Saksa esiaja ja kirjanduse uurimisel tehtud jõupingutuste tulemus. Muistenditest otsiti ja ka leiti igivanadest aegadest pärit mõttepilte (Grimm 1981), mütoloogilisi mälestusi ja tõendeid rahvapoeesiast. Vennad Grimmid jagasid oma esmakordselt 1816. aastal ilmunud ja peagi kaanoni ks kujunenud kogumikus DeutscheSagen rahvajutud kahte suuremasse rühma: kohamuistendid ja ajaloolised muistendid. ${ }^{1}$ Sellest mitte eriti õnnestunud vahetegemisest eel kõi geajal ooja eel kõigekohaga seotud (Grimm 1981: 13) juttude vahel on tänaseks loobutud usundiliste ja ajalooliste muistendite vastandamise kasuks, kusjuures muistenditest üldisemalt rääkides peetakse enamasti silmas esimesi. Ajaloolist muistendit loetakse ved suhteliselt vähe uurituks (Petzoldt 1976: 339). Kuuludes rahvajuttudetraditsioonilisteliikide hulka, elab see mõisteerialastes käsiraamatutes ja uurimustes ometi oma tagasihoidlikku elu. Asjaolule, et muistendiuurimine vajaks hädasti värsket verd, on hiljuti viidanud Helge Gerndt oma suundaandvas uurimuses (Gerndt 1986: $408 \mathrm{jj}$ ).

Minu käsitluse juhtmõte on: käes on aeg jätta hüvasti ajaloolise muistendi kui teaduslikku klassifikatsiooni kuuluva mõistega. Tulevikus tuleks seda terminit kasutada ai nult uurimi sajaloolise nimetusena juttude kohta, mida on 19. sajandi algusest peale nii nimetatud. Asendusmõistena pakuksin välja termini ajaloolinepärimus. ${ }^{2}$

Tees. J utu-uurimises on vaja asjakohaselt Iõpule viia ajaloolaste alustatud ajal ool ise pärimuse uuringud. Sama päevakajal ine on jõuda olukorrani, et ajaloolased hakkaksid tunnustama ka jutu-uurijate saavutusi.

Võib tunduda, nagu ei vajaks jutu-uurimine, mis vaatleb mõistega jutt määratletut kitsast erialast tingitud silmaklappi deta, mingit kaitsekõnet. U urimispraktika aga näitab, et tegelikult ei vahetata õi eti üldse vastastikku kogemusi. See nähtub juba asjaolust, et raskusteta võidakse kõrvutada kaht tegelikkuses täiesti haakumatut arutlusvaldkonda või paradigmat, mis määratlevad mõistet jutt soo- 
tuks erinevalt: ${ }^{3}$ nimelt vai dl ustest maagi liste vormel ite narratii vsus ja suul isus üle. Narratiiviuurijatel, kes tegel evad ajal oo ja juttudega (mit Geschichte(n)), on fil osoofia-, ajal ooteooria- ja kirjandusteadusealane teoreetiline taust. Uurijad, kes näevad folkloori eelkõige suulise rahvaluule kontekstis, on teoreetiliselt ettevalmistuselt märksa lõdvemalt seotud. Nende ühisnimetajaks on parimal juhul funktsional islikust lähenemi sest mõjustatud küsimus suuliselt levivate juttude kohast päikese all (vt viiteid Graf 1987a: 11). Kõik viitab sellele, et ilukirjanduse ja kollektiivselt vormitud folkloori ${ }^{4}$ idealistlikust vastandamisest loobutakse peagi praktilistel kaalutlustel. Samasugusele ühtlustumistendentsile osutab see, et suulise kõne uurimiselt kandub tähelepanu tõusvas joones kuhugi kirjaliku ja suulise vahealale, nimelt semioraalsusele (vt ka SchliebenLange 1983: $46 \mathrm{jj}$ ).

Seega tuleks ajaloolise pärimuse analüüsimisel kasutada nii ajaloolaste, folkloristide kui ka kirjandusteadlasteuurimistavasid ning saada ülevastastikustest eel arvamustest ja suhtlemi shirmudest. Põhimõttelisi metoodilisi erinevusi ju pole. ${ }^{5}$ E riti tuleb loota, et varasema ajaga tegel ev germanistika heidab kõrvaleammusest ajast kultiveeritud valearusaama rahvajutu-uurimisekohta, sest jutu-uurijad pole üksnes motiividejahtijad ja kogujad.

Tees. Mingi motiivi esinemine kirjanduslikus kontekstis ei välista sellemuid kasutusvõimalusi. Kirjandusteadus, mis ei arvesta jutumotiive, on pime. Motiivide kuhjamine nende konteksti arvesse võtmata on mõttetu.

\section{Ajaloolise traditsiooni funktsioon ja kandjad}

Frantiček Graus vaatleb 1975. aastal ilmunud suurteoses Lebendige Vergangenheit (Elav minevik), mille alapealkirjaks on Überlieferungen im Mittelal ter und in den Vorstel lungen vom Mittelal ter (Rahvapärimus keskajal ja kujutelmades keskajast) ühiskonda kujundavaid ja stabiliseerivaid traditsioone. I ga suurema rühma tekkega, väidab ta, kaasneb peaaegu paratamatult mingi traditsioon, mis aitab sellisel rühmal koos püsida (Graus 1975: 2). Ajal oolise traditsiooni all mõistab F. Graus möödunust kõnelevat jutustust, millel on oma tähendus käesol eval ajal, mis on ajaliselt ja ruumiliselt fikseeritud, mida ei anta edasi ainult lühikese aja vältel ja millel on mõju olnud ka puhtteadusliku uurimise val dkonnast väljaspool (Graf 1975: 6; 
vrd Graf 1984: 101, 169). Enamasti mõne isikuga (näiteks selliste suurkujudega nagu Dietrich von Bern, Wilhelm Tell, püha Wenzel, Karl Suur, Caesar, Siegfried, J eanne d'Arc või Friedrich I Barbarossa) seostuva pärimuse uurimine viib F. Grausi järel dusele:

Nende kohta käiv pärimus ei ol nud müütiline ega ka (vastavalt romantilisele käsitlusele rahvast) ürgne; kõigil uuritud juhtudel oli võimalik osutada tihedal eseosel eõpetlaste pärimuseja ajal ootundmi sevahel. Seeajal ootundmi netoetus ikka ja jällekroonikutele, võttis aga kirjali kult fi kseeritud pärimuseandmehulgast ai nult väi kese osa, töötles seda oma äranägemisejärgi ja rõhutas jutu funktsiooni, selle ühiskondlikku tähendust (Graus 1975: 374).

Ajal ool ise pärimuse funktsioon sei sneb seega integreerimisvõimes, mis tal oli teatava rühma või antud pärimuse kandja seisukohalt. ${ }^{6}$

F. Grausi lähenemise mõistmiseks on kasulik meenutada, et ta käsitles juba 1965. aastal oma uurimustes Merovingide aja hagiograafiast põhjalikult ja rikkalikule materjaliletuginedes rahvapärast jutupärimust varakeskaegsetes legendides (Graus 1965: 197-289). J uba siis märkis ta poliitilisemuistendi ajal ugu käsitleva uurimuse vajadust (Graus 1965: 277; vrd Graus 1969). Legendiline pärimus ajendas F rancesco Lanzonit kirjutama ajal ool iste fiktsioonide (l eggende storiche) teket, arengut ja hääbumist käsitl evat uurimust. See laiemale avalikkusele küll peaaegu tundmatu kirjutis ilmus 1925. aastal. ${ }^{7}$ Tegemist on ajal ool aste eksitusi ${ }^{8}$ käsitleva intrigeeriva uurimusega, milles lähtutakse ajaloolise kriitika traditsioonilisest küsimusest ajaloolise tuuma kohta. M. Bloch (1985: 23-118) sõel ub välja eeskätt kõikvõimalikud ajaloolise tõe moonutused ja deformatsioonid, et lõpuks vaadelda selle protsessi erinevaid põhjusi (Bloch 1985: 119-244).

Hagiograafiline pärimus, mida reformaatorid häbistasid kui luiskejutte (Lügend), on näide allikatest, mille peal on edukalt proovitud uusi, faktikesksest positivismist mõjustamata allikakriitilisi meetodeid. Friedrich Lotter on oma tähtsates metodoloogilistes hagiograafiaarutl ustes püüdnud seostada legendianalüüsi F. Lanzoni seisukohtade, moodsa piiblikriitika (vt Brückner 1979; Müller \& Köster 1983; Richter 1971; Theißen 1974), rahvajutu-uurimise ja vananorra jutukirjandusega (Lotter 1976: 1-20; 1979). Kahjuks kasutab ta aga küsitava väärtusega viitei d ül distel e pärimusseadustele peamiselt selleks, et leida pärimusest senitundmatuid ajaloofak- 
te. Lisaks F. Grausile on viimastel aastatel ka Klaus Schreiner toonud esile ajalool ise traditsiooni kujunemise tähenduse indiviidi ja rühma identiteedi loojana:

Ka muistendid kätkevad endas ajal ool isi kogemusi, ka muistendid täi davad kiriku ja poliitilisekogukonna elus teatavaid funktsi oone: nad õilistavad, õi gustavad ja kriti seerivad. Nad teevad seda eelkõige aja ja kohaga seonduvaid ajal ootõl gendusi uuesti juttudeks muutes(Schreiner 1986: 160; vt ka Schreiner 1975; 1977; 1979). ${ }^{9}$

Ühelokaalse näite põhjal avanes võimalus uurida ajalool ise pärimuse kandjaid ja funktsiooni. Kunagise ri gilinna Schwäbisch Gmündi allikad on ajalool ise jutu-uurimise allikakriitika (M oser-Rath 1973: 69) nõuetekohaselt rõõmustavalt tihedad ja või maldavad uurida 16. sajandi keskel esilekerkinud kroonikaid tavakohasel allikateadlikul viisil, aga saada sealt ka teavet traditsioonide tähtsusest linnale ja selle elanikkonna kihtidele (Graf 1984). ${ }^{10}$ Ühe Staufi ${ }^{11}$ pärimuse teket ja arengut on õnnestunud Gmündi sõrmusemuistendi näitel eraldi sel gitada (Graf 1982). Selle pärimuse hilisemal käsitlemisel formuleeriti ühtlasi ajalooliste muistendite üldisemaid probleeme (Graf 1987: 84-134), ${ }^{12}$ mille juurde tulen järgnevas veel kord tagasi.

Gmündi sõrmusemuistendi erinevate variantide olemasolu annab võimaluse lähtuda ühest konkreetsest näitest, et jõuda välja üldisemate küsimuste ja probl eemideni. Esimene kõnealuse muistendi kirjalik ülestähendus pärineb aastaist 1595-1596 ja sisaldub laialdaste ajalooalaste teadmistega Tübingeni õpetlase Martin Crusiuse ladinakeel ses teoses Annales Suevici . Lisaks Iadinapärase linnanime Gamundia traditsioonilisele tuletamisele nimest Gaudia mundi teatab M. Crusius vastavasisulisest leiust lähedalasuva L orchi kloostri munkaderaamatus. Švaabimaa hertsogi Friedrich I ${ }^{13}$ abikaasa hertsoginna Agnes ${ }^{14}$ ol evat kaotanud abielusõrmuse. Pika otsimise peale ol evat see leitud kohast, kus praegu paikneb Gmünd. Tõotuse kohaselt rajati sinna linn ja nimetati see Gmündiks, et sellega öel da: rõõmusta, maailm (Gaudemunde), sõrmus on leitud! M. Crusius kommenteerib: "Aga sellejätan kõrvale, sest see on küsitav. Sest hiljem leidsin mujalt, et sel põhjusel ei rajatud Gmünd, vaid üks klooster."J ärgmine teade pärineb 1620. aastast, mil Gmündi jurist Leonhard Friz seostab pärimuse erinevalt M. Crusiusest Gmündi Püha J ohannesekirikuga: “Rahvasuus räägitava jutu hertsog F riedrichi naise Agnese abielusõrmuse leid- 


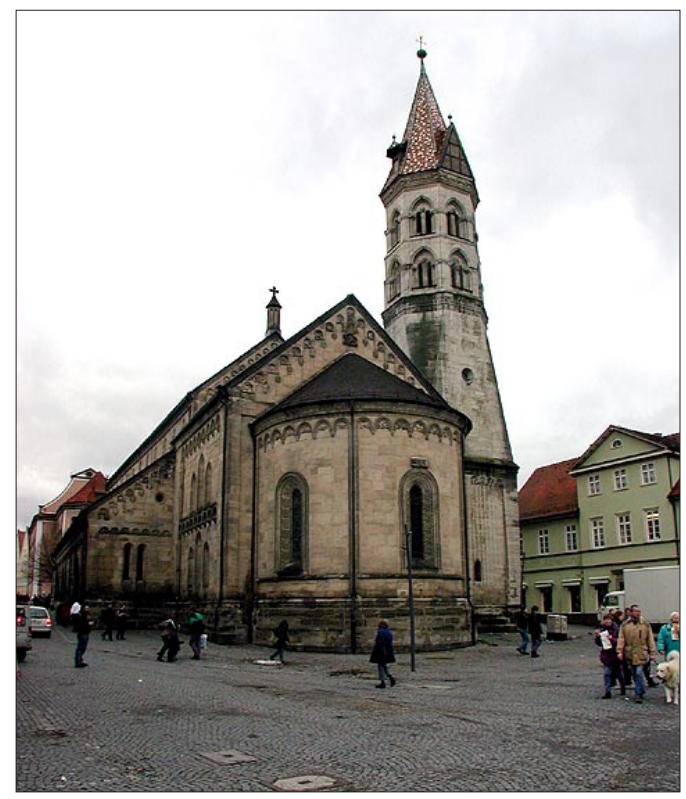

J oonis 1. Schwäbi sch Gmündi J ohannesekirik. Seehilisromantismi sakraalarhitektuuri kaunis näide on ehitatud aastatel 1220-1250 kolmelöövilise sammasbasiilikana varem samal kohal asunud kiriku vundamendijäänustele Pikihoonekõrval kõrguv torn on Švaabi maa kauneimaid (www.public.iastateedu/-kmoloney/ FIL/Chapters/newYear/gmund/square.jpg).

mise kohta jätan ma kogu selle tões ja vales sinnapaika." Seevastu kroonik Friedrich Vogt arvab 1674. aastal, et midagi peab sellejutu taga siiski olema. Ta tugineb "üldtuntud loole", mille järgi Agnes ol evat kaotanud sõrmuse J ohannese kiriku kohal. J ärgneb sõrmusemuistendist lähtuv J ohannese kiriku arhitektuurse vormi põhjalik tõlgendus. J ohannese kiriku altariküljel asub tänapäevani Gmündi kunstniku Heberle maal aastast 1714, mis toob meieni mitmed sõrmusemuistendi stseenid koos sel gitavate päiskirjadega.

Selle pärimuse kohta võiks esitada kolm küsimust, need puudutaksid 1) ajal ool ist tuuma ja sell e seost ajal ooteadmistega, 2) edasiandmisviisi (suulineja/või kirjalik), 3) algvarianti. Seoses sõrmusemuistendiga võiks niisiis esitada järgmised küsimused. 
1. Kas sõrmusemuistend on tegelik mälestus Staufi hertsogipaarist või õpetlaslik kombinatsioon humanismiaegsetest ajalooteadmistest?

2. Kas sõrmusemuistend on suuline muistend või ümberkirjutustes kujunenud ja haritud ringkondades edasi antud traditsioon?

3. Kas sõrmusemuistend on algselt seletusmuistend J ohannese kiriku arhitektuurse vormi kohta või mõne didaktiku läbimõeldult konstrueeritud eksempel?

Need küsimused keskenduvad, tõsi küll, valedele alternatiividele. Mäl etami se kontseptsiooni pole vaja vastandada kombineerimisele, samuti pole mõtet lahutada ajaloolisi muistendeid haritlastetraditsioonist. Ühest al gvariandist lähtumine takistab pärimuse vaatlemist selleerinevates versioonides. Kõneal use arusaama kohta on all pool esitatud pikem sel gitus.

\section{Mäletamine versus ajalooline kujunemine}

L oomulikult on meil õigus võtta mingit teatud traditsiooni väljakutsena, uurida objektideja sündmuste ajalugu, millest seetraditsi oon näib rääkivat. Nii võib näiteks väite, et hiliskeskajal ja varasel uusajal oli Gmündi J ohannese kirik teatud mõttes relikt ja põhjustas seega sõrmusemuistendi kui etioloogilise pärimuse kujunemise, võtta aluseks teesile, et aristokraatliku memoriaalehitise ja sakraalse valitsejaesindusena mõjuva J ohannese kiriku püstitasid Staufi suguvõsa ja Staufi-meel sed aadl ikud (vt Graf 1987: 116-119). Niisuguse spekulatsi ooni puhul ei tohi aga sattuda eksiarvamusele, nagu olekski see sõrmusemuistendi ajalooline tuum.

Tees. Rääkida mingi pärimuseajal oolisest tuumast on kas triviaalne või ohtlik. Ohtlik juhul, kui sell ega tahetakse tõestada suulise pärimuse usal datavust või allikaväärtust või toetada mõnd puuduliku allikmaterjali põhjal püstitatud spekulatiivset väidet.

Moodsa piiblieksegeesi metoodilise põhimõttena formuleeris Klaus Koch järgmise väite: pol e võimal ik redutseerida muistendeid neis sisal duva ülel oomuliku ja või b-ol la ka ebatõenäol ise mahatõmbamise teel ajaloolise tuumani ja monteerida need siis ajalookäsitlustesse, nagu polekski olnud tegemist millegi muu kui ajalooliste sündmustefantaasiarikka kaunistamisega (Koch 1974: 188jj). Ometi leidub ikka ja jälle Heinrich Schliemanni tüüpi uurijaid, kes püüavad müüti dest, muistenditest, muinasjuttudest ja eepilistest suur- 


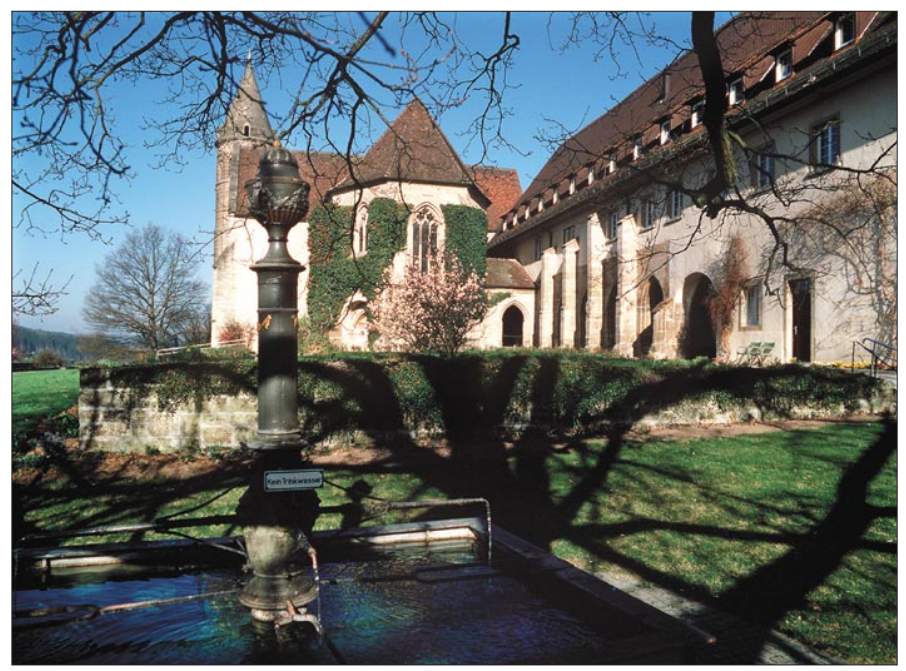

J oonis 2. Lorchi klooster. Pärimusejärgi asutasid kloostri 12. ja 13. sajandi vahetuse Švaabimaa hertsog Friedrich I ja tema kaasa, Saksa-Rooma keisri Heinrich IV tütar Agnes von Franken Staufide (Hohenstaufenite) matmispaigaks (www.schloessermagazin.de/image/pressefoto/2503/kloster-lorch.jpg).

teostest leida ajaloolist tõde ja kaitsevad seda siis kangelaslikult $\mathrm{nn}$ teadlaste tsunfti tagakiusamise eest. ${ }^{15}$

Hiliskeskajast peale on allikaliselt tõestatud ajal ool ised pärimused, mis ülistavad Schwäbisch Gmündi Staufi-aegse hertsogiresidentsi, Staufide lõbustuspaiga ja Gaudia mundina. Staufi pärimus - mälestus Staufide hiilguse rajajatest - oli linna al gusaegade ajaloopärimuse teljeks. Humanismiajal tugevdasid õpetlaspärimused paikkondlikku patriotismi veelgi. Tõsiasi, et sõrmusemuistend on vaadeldav sellepärimusekontekstis, selgubjuba siis, kui M. Crusius seda esmakordselt mainib: ta vihjab Gaudia mundi etümol oogiale. Gmündi rajajad Agnes ja Friedrich on ühtlasi tuntud kui naabruses asuva Lorchi kloostri ehk Staufi suguvõsa matusepaiga asutajad. Märkimisväärne on asjaolu, et $M$. Crusius väidab, nagu oleks ta arvatavalt õpetlaste loodud sõrmusemuistendi versiooni leidnud Lorchi munkade raamatust. Pole välistatud, et just Lorch oli koht, kust üldtuntud kohamuistend Kirik ehitatakse ülesl eitud sõrmuse kohale kanti 15. sajandi Iõpus või 16. sajandi alguses üle Gmündi J ohannese kirikule ning seostati Lorchi rajajatega. Olgu sellega 
kuidas on - igatahes enne, kui hakata mõtlema, et tegemist võiks olla sajanditevanuse Staufi-aegse pärimusega, tuleb endale teadvustada, et hertsogipaar Friedrich ja Agnes olid 16. sajandil õpetlaste ajal ooteadmistes piisavalt tuntud.

Üllataval kombel võis sajanditepikkuse iseseisva rahvatraditsiooni klišeed kohata veel hiljuti Konstanzi ajaloolase Helmut Maureri töös Karl Paksust kõnelevates Neudingeni muistendites (Maurer 1984). Maurer konstateerib, et alates 18. sajandi teisest poolest on kujunenud mitmete variantidena esinev paikkondlik traditsioon, mis seondub 888. aastal Baari maakonnas Neudingenis surnud Karl II Iga. Tema väide kõlab järgmiselt:

Neudingenis ja Neudingeni ümbruskonnas on sõltumatult ajalooki rjutusest ja ki rjalikest jutustavatest allikatest kujunenud muistendid Karl III surmast ja tema igavesest tagasi pöördumi sest deemonina. On tõenäoline, et need muistendid on taandatavad kitsalt piiritletud alal elaval esuuliselerahvapärimusele Karl III surmast Neudingenis. [---] Võib näha, et Neudingeni ja Pfohreni talurahval on ol nud ja on osalt tänini oma ajal ootõl gendus, oma nägemus minevikust, oma käsitlus keskajast (Maurer 1984: $97 \mathrm{jj}$ ).

Maureri artiklit lugedes kerkib esile hulk kriitilisi küsimusi. Kas on võimalik, et Neudingeni talurahvas on rohkem kui kaheksasada aastat mäl etanud ühe kohaliku Karolingi valitseja surma, ja nagu näib, isegi ilma tema liturgilisel e mälestuspäeval etoetumata? Kuidas on pärimus teda sel juhul identifitseerinud, s.t eristanud eelkõige üldtuntud rajajast Karl Suurest? Kas pärimusena anti edasi kellegi nimetu keisri, keiser Karli või hüüdnimePaks kandva keisri surm? Kas see identifitseerimine pole siiski õpetlaskonna lisand? Maureri tsitaat selle muistendi vanima üleskirjutuse kohta pärineb kohaliku tsistertslaste kloostri käsikirjalisest kroonikast aastast 1770 ja al gab järgmiselt: Üldtuntud muistendi [saksa k Sage, tõlgitav ka kui kuuldu - R.H.] järgi ol evat äsjakroonitud keiser need kaks aaret [---] pandiks andnud. Sellele eelnevad, nagu ma oletan teksti sõna-sõnalt tundmata, õpetlaskonna mõtteavaldused Karl I II kohta. Vähemalt oma vanimal fikseeritud kujul on N eudingeni pärimus ajalooteadmiste ja kohaliku pärimuse kombinatsioon, kusjuures jääb selgutsetuks, mil määral see suuline pärimus ise on ajal ooteadmistest toitu saanud. Maurer peab isegi möönma, et surmapaika Neudingeni nimetati rahvakeelses historiograafias juba 
1500. aasta paiku. ${ }^{16}$ See, nagu võiks ajalookirjutuse mõju välistada, sest vastasel juhul tuleks loobuda väidetava mõrva vaatemängulisest motiivist, on üsna nõrk argument. Vähemalt tänapäevaste pilkesalmide puhul (Kaiser Karl der Dicke, der im Dreck erstickte, eesti k: keiser Karl Paks, kes uppus mustuses) tuleb kooliõpetuse mõju küll kõne alla. Kas ei ole võimalik, et näiteks aardejutu motiivid seostati teatud valitsejaga (kuningas, keiser) ning seevalitseja samastati koolis saadud teadmiste toetusel Karl I I ga, mis omakorda viis edasiste muistendite väljakujunemisele? Asjaolu, et valitsejad legendilaadsetele pärimustele autoriteeti lisavad, on levinud nähtus ega vaja tingimata mingit reaalset ajendit..7

Ajaloolistel pärimustel on allikaväärtus, mida on võimatu alahinnata (Maurer 184: 99) - seda aga traditsioonikujundajana, mitte seetõttu, et need tõendaksid rahva aastasadadepikkust mälu või nn rahvapärase ajaloonägemuse sõl tumatust.

Tees. Mõiste rahvapärane ajal oonägemus on kõlbmatu, sest mõisted rahvas ja ajalugu pole piisavalt ühemõttelised.

Väheviljakaks tuleb seega tunnistada ka alles hiljuti esitatud Guy P. Marchali vaatenurk: Ajal ool ised muistendid määratl etakse ja neid kantakse edasi rahvapärases ajal ooteadvuses, milleväljenduseks nad omakorda on (Marchal 1984: 533). ${ }^{18}$ Mis puutub mõistesse rahvas, siis peatun sellel allpool pikemalt. Siinkohal piisab vihjest ebakõlale, mis tekib rahvapärase ajal oonägemuse interpreteerimisest alamkihi kontraajaloona, ja arvamusest, nagu oleks sellega mõeldud mingit antropoloogilises mõttes konstantset ajaloolist meel t, n.-ö rühmaspetsiifiliste ajal ootunnetuste ühisnimetajat. ${ }^{19} \mathrm{~N}$ atuke põhjal ikumat tähel epanu tuleks pöörata mõisteleajalugu, sest sellest loobumisel tuleks ühtlasi hüvasti jätta mõistega ajalool inemuistend ja teatud mõttes ka asendusmõistega ajalool ine pärimus. See termin ei seostu aga niivõrd mõistega ajalugu, kuivõrd F. Grausi vaieldava definitsiooni ja tema vaadeldud paradigmaatiliste pärimusterühmaga. Problemaatilise lisandita ajal oolinevõiks seda parafraseerida ka kui isi ku- ja sündmusepärimust.

Teatud mõttes või b iga muistendit käsitl eda ajalool ise muistendina, sest muistendid jutustavad alati ajal oost, möödunust (Psaar \& Klein 1980: 65). Mis on aga ajaloolistes muistendites nii spetsiifiliselt ajalooline? Piiblieksegeesi suhtes on Wolfgang Richter rõhutanud nn ajalooliste Vana Testamendi osade küsitavust kaanonina ning hoiatanud 19. sajandi ajaloomõistekasutamise eest lugude klas- 
sifitseerimisel (Richter 1971: 129, 188 jj, märkus 60). Oma uurimuses kreeklaste ajaloolise mõtlemise tekke kohta kaitses Christian Meier argumenteeritult seisukohta, et tuleks hoiduda kõi gist moodsa ajaloomõistehal badest varjunditest (Meier 1980: 367). Meier tegi suurepärase ettepaneku: Kui varastekultuuri demõtlemi st ja meele laadi puudutavates aruteludes pi irata sõna ajal ool inekasutamist, tekiks ehk tervendav sund täpsemalt väljenduda (Meier 1980: 386, märkus 33). Teaduskeelseajaloomõistekriitikat on võimal ik toetada ka mõisteajal oo pinnalt. Alles valgustusajastul, umbes 1770. aastal kerkis esileainsusevormiline termin ajalugu (Geschichte), alles siis kivines üldmõisteajal ugu spekulatiivseks konstruktsiooniks (Koselleck 1979: 38jj). ${ }^{20}$ Ai nuke, mi da või bajal oo (Geschichte) kui sel lisekohta väita, on see, et setoi mub (geschiecht). J a sel lega pol emittemi dagi öel dud (Demandt 1978: 453). Konkreetsetest historiograafilistest tekstidest eemal seisvaid aprioorseid spekulatsioone (vrd nt Gumbrecht 1986; Rüsen 198621) trotsides pole ma siiski arvamusel, nagu eksisteeriks mingi ajal oomeel kui inimeseel ementaarnevõime(Schott 1968: 187).

Tees. Mõiste ajalooline mõtlemine on muutlik rühmaspetsiifiline kokkuvõte erinevatest, Ludwig Wittgensteini mõistes perekondlikult sarnastest keelekasutusliikidest.

Mõiste mäng näitel on L udwig Wittgenstein juhtinud tähelepanu sellele, et üksikutel mängudel võib küll olla mitmeid kokkupuutepunkte (mis on võrrel davad sarnasustega perekonnas), mille puhul aga pole võimalik lähtuda ühestainsast, kõigi kohta kehtivast defineerimistunnusest. Mängude sidususe kohta kirjutab ta: Lõnga tugevus ei tulene mitte sel lest, et üks kiud jookseb läbi kogu lõnga pikkuse, vaid sel lest, et hulk kiudekattub üksteisega (Wittgenstein 1977: nr 67; kirjandust vt ka Graf 1987a: 18 ja märkus 51). Kes üritab määratleda ajal oo ol emust, peab seega tegema valiku kompleksses mõistevõrgustikus (vt ka Demandt 1984: 172 jj).

Peale ajal ookontseptsiooni tuleks val gustada kriitiliselt ka pärimuse oma. Eeskujud hoiavad meid vangis (Wittgenstein 1977: nr 115), kui räägime pärimusest kui protsessist. Populaarne on näiteks mäl etami semetafoor. Kuigi seda on ajal ooteoreetilistes aruteludes kasutatud korduvalt universaalse vahendina (kriitikat vt Graf 1984: 12),22 ei arvesta see õpetlaste ega lihtrahva kombinatsioonideja spekulatsiooni dega. Arusaam traditsi ooniahel ast ajal ool isefakti ja pärimuse vahel on orienteeritud kujutelmale teatavast päritavast tõegeenist, mis aval dub variandist varianti ning lähtub traditsiooni kulgemise mudel ist, mille saab konstrueerida järgmi selt: suh- 
Staufid (Hohenstaufenid) ja Lorchi klooster gooti freskodel
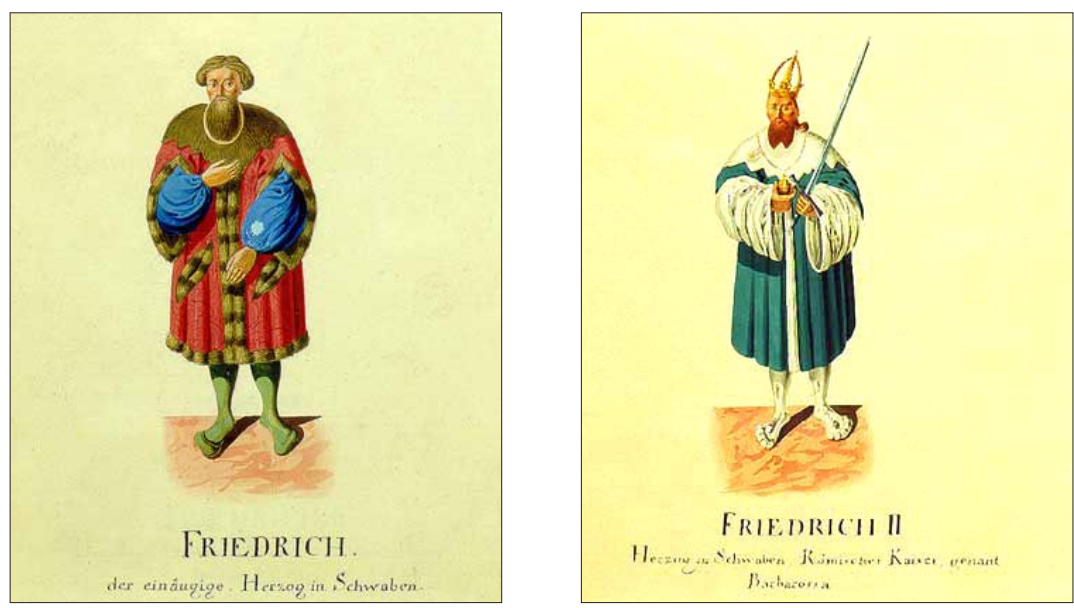

J oonis 3 ja 4. Kaks kuulsat Staufidesoost meest, keda tänapäeval tuntakseFriedrich I nimeall: paremal: Švaabi hertsog F riedrich I (1047-1105) ja vasakul Saksa-Rooma keiser Friedrich I Barbarossa (1123-1190); pildid http:// www.schloesser-magazin.de.

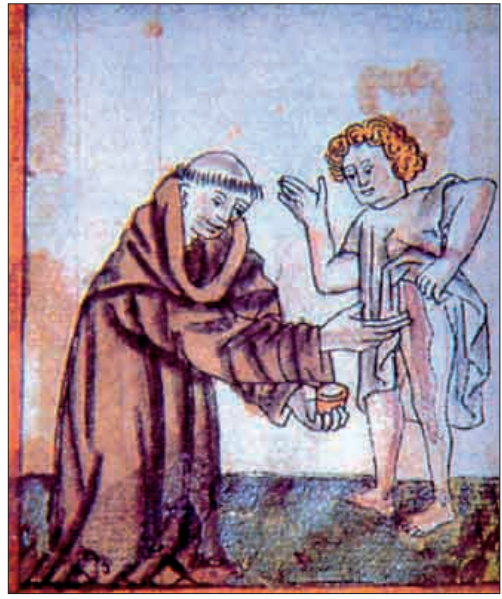

J oonis 5. Lorchi kloostris elasid kuni sellelikvideerimiseni benediktiini mungad (http://www.schloessermagazin.de).

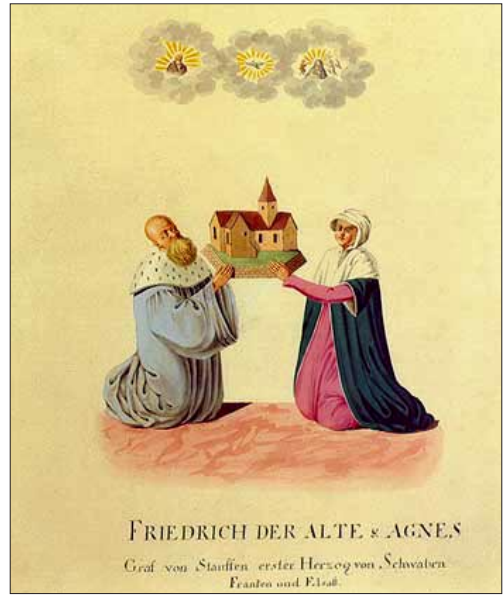

J oonis 6. Lorchi kloostri rajajad Švaabi hertsog Friedrich I ja tema kaasa Agnes (http://www.schloessermagazin.de). 
teliselt suletud rühmas antakse mingi ajal ooline teade paljude põlvkondade jooksul edasi vanematel t lastele. ${ }^{23} \mathrm{~K}$ es toitub ainult sedalaadi näidetest, peab kahtlemata üsna ühekülgset dieeti. ${ }^{24}$ Tegelikult on suuline pärimus, nagu on välja selgitanud moodne jutuuurimine (vt nt Moser 1982: 120), segajate suhtes ülimalt tundlik.

Ühe õpetliku näite on hiljuti toonud Guy P. Marchal. Ta arutleb 1436. aastal üles kirjutatud pealtnägijate tunnistuste üle haihtunud silla kohta Luzerni lähedal ja konstateerib, et ühesseneist tunnistustest on sisse lipsanud jututüübi AT 1645 motiiv N531 aardeunenägu sillal (Dream of treasure on thebridge). G. P. Marchal teeb järel duse:

Kujutlus eksimatust, igal hetkel kõige vanemate isikute tunnistustel põhinevatest kollektiivsetest mälestustest, mis on põlvkonnalt põlvkonnale muutumatult edasi kandunud, vajab [---] hädasti kontrollimist (Marchal 1984: 538).

Siinkohal on võimalik üksnes märkida, et arhiivimaterjali poolest rikkalikult esindatud peal tnägija tunnistusel e saab ajalool istesündmuste ja asjaolude individuaalse mäletamise küsimuses toetuda paradigmaatiliselt. Sageli ei tea tunnistajad näiteks oma täpset vanust või ei dateeri täpselt mingit läbielamist, mistõttu need ajastatakse muude, kergesti meeldejäävate sündmuste järgi, näiteks: mäletatavasti siis, kui rohutirtsud maalesaabusid (Wollmershäuser 1977: 352). ${ }^{25}$ Pealtnägijate tunnistused annavad võimal use mäl etamisvõi met rühmaspetsiifiliselt diferentseerida (Tremp-Utz 1986).

Välja pakutud liiga lihtsustatud pärimusprotsessi skeem vajaks seega väljavahetamist mõne komplekssema mudeli vastu, milles suulised ja kirjalikud pärimuskiud oleksid tihedalt põimunud. Ajaloolise isikupärimuse kohta märkis Hel ge Gerndt (1980: 445 ) järgmist: Mälestust mingist ajaloolisest isikust ei anta edasi ühetaoliselt ja ühekül gselt, et näiteks lihtsad ini mesed ai nult suul ises-mäletatavas vormis, õpetl ased ainult kirjalik-teadusl ikus vormis. Kui aga tunnistada, et muistendil või bolla ka kirjalikkeeeskujusid, ei pääse mööda F. Grausi (1975: 12) tabavalt sõnastatud väitest, et mõnigi ajalooline pärimus on osutunud dokumentaalajal ool ise teadusliku uurimistöö ebaseadusl ikuks lapseks.

Pärimusahela kontseptsiooni võib kõrvutada kombineerimiskontseptsiooniga, mille all tuleb mõista teadlikult või teadmatult (ehk mutatsiooni käigus) ajalookriitika meetoditega või ilma nendeta tehtud valikut teatud motiivide hulgast, nende omavahelist seostamist ja üksteisesse sulandamist. Seda kontseptsiooni vaadel- 
dakse jutu-uurimises peamiselt seoses jutustaja subjektiivse loovuse kui pärimust segava faktoriga (vt nt Dégh 1984: 326 jj).

Pikemat aega ringel nud pärimus, nagu seda on näiteks sõrmusemuistend, on kindlasti kujunenud nendekahekontseptsiooni mitmekordse ristumise tulemusel. Kui aga pärimusahelas tekib kombineerimise tõttu mõni lünk, osutub biologistlikes arusaamades esinev sisutuumakujutelm (Substanzdenken) eksl ikuks. Pärimuste ajal oolise tuuma juures tuleb siiski tavalisest rohkem arvestada võimalusega, et mitte ainult kriitiline uurimine, vaid ka ajalooharidusele toetuv ettevaatamatu spekulatsioon või bjuhtumisi naelapead tabada.

Puhtalt pärimusahelast lähtuja on sunnitud raskuskeskmeasetama ahela esimesele lülile. Küsimus ajal oolise sündmuse ja pärimuse eril isest seosest taandub seega küsimuseks, millist laadi suheon sündmuse ja selle kirjelduse vahel - ühelt poolt jõutakse referentsi ja intentsionaal suse fil osoofilise probleemi, ${ }^{26}$ teiselt poolt tradeerimisprotsessi seaduspäradeni. Tabavaks, s.t objektiivselt põhjendatud ja aktsepteeritavaks kirjel duseks saab teatud hetke kogemuse tunnistada siiski alles ex post, s.t varustatult ajaloolise taustaga, mida vahetu pealtnägija ei saa teada. Kui nii võtta, siis jookseb siin historistlik kihk teada saada, kuidas on asi tegelikult ol nud, võidu hermeneutilise, ajal oolise mõju väljasel gitamisele orienteeritud siiliga.

Tees. Ajaloolist pärimust tuleb vaadelda omaaegsest ajaloolisest kultuurist ${ }^{27}$ lahutamatult, s.t eel kõige koos rühmaspetsiifilise ajaloolise kujunemise, aga ka mitteverbaalse meediaga: riituste, piltide ja esemeliste tähistega.

Poletõsi, nagu ol eksid ajalooraamatud alles 19. sajandil saanud toota suulisi muistendeid: juba 16. sajandist on andmeid, et jutukogumikke oli ka talurahva ja käsitööliste valduses. ${ }^{28}$ Tänapäevalgi Gmündi J ohannese kiriku kooril vaadata olev Gmündi kunstniku sõrmusemuistendi pildiline kujutis koos päiskirjadega suutis hoida kiriku loomisloo kogu aeg vahetult kättesaadava. Pildiliste kujutisteja päiskirjade tähendust pärimuse edasiandmisel ei osata üldjuhul piisavalt hinnata (vt Graf 1984: 159, 166, 185).

Nn linnapiiramismuistendite näitel on võimalik vaadelda, kuidas sündmuste ümber kujuneb erinevate meediumi te mäl estuste ring. ${ }^{29} \mathrm{~J}$ utumotiivide (näiteks piiramiskaval uste) al usel muistendikogumikesse sattunud pärimusi linnade piiramisest tuleb vaadel da koos linliku omadiskursusega, ${ }^{30}$ ni isiis koos linliku identiteedi sel gitami sega väljastpoolt lähtuva ohu ol ukorras. Seejuures tuleb silmas pidada mitte ainult historiograafilisi ülestähendusi 
või ajaloolisi laule, vaid ka rituaal seid ja esemelisi tõendeid. Linna ülemkiht ol i üldjuhul huvitatud sellest, et näiteks mälestus üleelatud pi iramisest säiliks avalikus mäluruumis. Sellevormid (aastapäev koos mälestusjumalateenistusega, mälestuskabel, piiramisjälgede konserveerimine) langevad kokku 14.-16. sajandi E uroopast meieni jõudnud näi detega.

Sageli liitublinnakäsitööliste pärimus ametlikult toetatud traditsiooniga, kui mõni käsitööline või kogu tsunft jõuab tänuks vapruse eest pärimussevõi saab koguni mõneerilise privileegi. Tsunftimuistend kui tsunfti omadiskursuse osa ning linna ametlik omadiskursus toetavad teineteist: tsunfti privileeg on linnale kasulik, sest linnal on võimalus pakkuda teistele tsunftidele eeskuju ja eksemplit kodanike vaprusest. Samalaadneliitumineperepärimusega on aset leidnud Lüneburgis, kus üks raehärra meenutab 16. sajandist pärit ladinakeelses hauakirjas oma pereliiget, kes oli langenud 1371. aasta Ursulaööl, ${ }^{31}$ kaitstes linna ühe linnakodaniku kallaletungi eest. Samamoodi olevat tema ise, kirjutab raehärra täis uhkust, kodulinna heaolu enda omast kõrgemaks seadnud ja oma kodulinna armastanud.

\section{Rahvamuistend ja lihtrahvas}

J ärgnevas püütakse leida argumente väitele, et haritlasl ikku konteksti, millesse on paigutunud ajal ool ise pärimuse variandid, ei tohi mõista kui välist kesta, mille taga muistend - aastasadu lihtsate inimeste seas suuliselt edasi antud täiesti iseseisvate tunnustega pärimus - ainult ootab taasavastamist.

M õttelerakendada Gmündi kroonikate (Graf 1984: 157-170) ajaloolise pärimuse analüüsimisel eraldi pärimustüüpi ajal oolinemuistend viis mind mitteniivõrd rahvajutu-uurimise senine traditsioon, kuivõrd avastus, et mõned lood on ajalooallikatesse jõudnud alles hiljuti ja osutavad nn rahvajutule või muudele sellesarnastele väidetele toetumise tõttu justkui suulisele levikule. Nüüdseks olen jõudnud veendumusele, et niisuguse isoleerimise tõttu - vähemalt sõrmusemuistendilaadse pärimuse puhul - sattusin ise lõksu. Ü ritades tõestada oma tollase järel duse ekslikkust, tahan ühtlasi sõna võtta mõisteajalool põhineva jutu-uurimise eestkosteks, mis võtaks uuesti kaalumisele küsimuse, kuivõrd on üldse praktilistel uurimiseesmärkidel võimalik rakendada osutusi rahvajuttudele, ning arvestaks sealjuures ka ajaloolaste uurimistulemusi avaliku arvamuse ja lihtrahva rolli kohta. 
Leonhard Friz tembel das 1620. aastal sõrmusemuistendi hal vustavalt kuulujutuks ning juba M. Crusius ol i pi isava selgusega väljendanud oma leiget suhtumist Lorchi munkade loosse. 1674. aastal püüdis kroonik F. Vogt seda üldtuntud juttu ilmselgelt niisuguste rünnakute eest kaitsta, viidates ühele konkreetsele trükis ilmunud tööle (Ulmis tegutsenud ja rohke kirjatööga silma paistnud Zeilleri omale, milles autor toetus M. Crusiusele). F. Vogti versioonile, mille järgi kaotatud sõrmust ol evat ehtinud pöörituse vastu aitav imekivi ning sellest tulenevalt olla J ohannese kiriku torni nimetatud Pöörituskiviks (Schwindelstein), räägib vastu rahvasuus torni kohta kasutatav nimetus Mähkmekivi (Windelstein). F. Vogt püüab seda tema arvates ekslikku nimevormi kummutada torni ehitusliku eripära kaudu, sel etades seda kõnekeel es Iühenenud nimena.

F. Vogti õpetlaslik argumentatsiooniahel väärtustab ühest küljest rahvamuistendit (gemeineSage), sest ta tahab põhjendustes lähtuda pärimusest, teisalt aga taunib lihtrahva (gemeine Leute) kõnepruugis levinud (ja 14. sajandist ka allikaliselt tõestatud) kirikutorni nimetust. Siinkohal tul eks mõnesõnaga meenutada adjektiivi gemein tähendusajalugu mõistena, mis on ühtlasi osake sotsiaalajal oost, kui mõel da põhjapanevaletähendusele, millelihtinimese (gemeiner Mann) toopiline rollifiguur (Kleinschmidt 1982: 169, märkus 345) omandab reformatsiooniaja poliitilises kultuuris. ${ }^{32}$ Ü helt poolt on sõnal gemein ('lihtne', 'keskpärane', ka 'lihtlabane') negatiivne varjund, kui seda kasutatakse vastandmõistena mõistetele poliitiline ja vaimne eliit, juhtladvik ja õpetlaskond. Teisalt seostub see teatud ühiskonnamudeliga, mis tunnistab lihtinimese (gemeiner Mann) ühiskondlik-poliitilise korra kandjaks. Kui tagasi pöörduda jutustamise juurde, siis tuleb viiteid rahvamuistendile (gemeineSage) mõista lähtudes vastuol ust ühelt poolt suulise argikultuuri üldkehtivaks pidamiseja teiselt poolt õpetlaskonna tõrjuva suhtumine vahel lihtrahva arusaamadesse. Ka ei tohi jätta kahe silma vahele asjaolu, et humanismiajal avastati rahvas kui sellinening rahvalik kõnepruuk, mida arvati väljenduvat vanasõnades, sai õpetlastearutlusteemaks (vt Zehnder 1976: 23 jj; haritlaste huvist vanasõnade vastu vt nt Davis 1984).

Mõistes gemein eneses peituvad vastuolud on hõlpsasti märgatavad ka mõiste rahvas juures: mudel, mis rõhub ülemkihi ja alamkihi, haritute ja harimatute dihhotoomiale ning kasutab mõistet rahvas lihtrahva, lihtsate inimestetähistamiseks ja vastandub terviklikkust taotlevale mudelile, mis püüab kaotada mõistest rahvas grupivastuolud (vt Guth 1984: 43; Brückner 1985: 16). Probleemid, 
mis seostuvad hiljuti ajaloolaste poolel sama ootamatult avastatud rahvakultuuriga (Dinzelbacher \& Mück 1987), tulenevad samuti suuresti mõisterahvas ettevaatamatust puhtantinoomilisest tõlgendamisest. Oleks kasulik võrdlevalt ja kriitiliselt vaagida erinevate teadusharudekäsitlusi mingi kindla epohhi - näiteks hiliskeskaja - kohta, kus opereeritakse endiselt mõistetega rahvapäranevõi selle sugulasterminitega. Sealjuures tuleks eriti tähelepanu pöörata hegemoonia või eraldatuse (millega on ehk liiagagi palju tegeldud) ning rühmadevahelise konsensuse vahekordadele. ${ }^{33}$

Üht probleemset ala puudutab sealjuures E rnst Schuberti ja tema õpilase Martin Baueri püstitatud küsimus hiliskeskaja avalikust arvamusest, moodsamalt sõnastatuna: aval ikkusefoorumitest hiliskeskajal (Schubert 1975). ${ }^{34}$ Kroonikates ja muus kirjasõnas leiduvaid teateid iseloomustatakse lisamärkustega rahvamuistend (geméne Sage), kuulujutt (gemeines geschrey) ja need väljendavad rohkem kui üht kogukonda või rühma hõlmavaid arusaamu ajaloolistest sündmustest ning neid tuleb võtta kui kompromisside ja pärimusprotsesside tulemust, s.t kui konstruktsiooni ning seega mitte kui suhtumist, mis on omane sellisele fiktiivsele suurusele nagu rahvas. Avaliku arvamuse puhul valitseb alati oht, et sellega võidakse mingi rühma huvides manipuleerida. See, mida pakutakse välja rahvajutuna, pretendeerib üldisele kehtivusele - sotsioloogiliselt fikseeritava teabekandja määratlust pol e seega antud.

Vormelid, mis viitavad lihtsalt jutulevõi üldtuntud muistendi le, ei tähista seega reaalset levikeskkonda, vaid on osa kelemängust (Ludwig Wittgensteini kasutatud tähenduses), mida on keeleliselt võimalik kaasata jutustaja öel dud tõendavatessevõi kahtlusealla seadvatesse vahelepõigetesse. Kui vastav kontekst või valitud väljend (L. Frizi gemeines Geschwetz versus F. Vogti al lgemeines Gesag) näitabki mingit hinnangut, on need vormel id ol emusl ikult siiski mitmemõttelised. Need või vad nii tõendada (kui neid kasutatakseüldkehtivas tähenduses) kui ka distantsi luua (kui need lai davad öel dut kui tühja juttu).

Asjaolul, et sõrmusemuistend Gmündi 16. sajandi kroonikates puudub, võivad olla mõnevõrra teistsugused põhjused kui see, et seda muistendit kui suuliselt levivat rahvajuttu ei peetud algselt kroonikasse kandmise vääriliseks. Võis juhtuda, et mõni kroonik unustas selletahtmatult, mõni aga jättis teadlikult välja, sest lool puudus talle teadaolevate autoriteetsete kirjalike allikate kinnitus. Herbert Grundmanni sõnastatud seisukoht, et aastasadu kirjasõna peal ispinna varjus elanud muistendivara jõuab hiliskeskajal ajalookirjutusse 
(Grundmann 1978: 168), ei tohiks meid viia selleni, et hakkamekõike kroonikates natukenegi rahvajutuna kõlavat muistendina reklaamima. ${ }^{35}$ Selle põhimõtte järgi on valitud valdav enamik vendade Grimmideraamatus DeutscheSagen leiduvaid ajaloolisi muistendeid. Kaalumist vajab, kas pole ehk juba varasel uusajal täheldatav rahvapärimuses ja trükiteostes esinevate jutumotiivide kattumine - eelkõige legendideja proosavormis ajalookirjelduste(Prosahistorien) osas - olnud otsustav nende paigutamisel rahvajutu alla. Asjaolu, et L. Friz 1620. aastal sõrmusemuistendi kui rahva seas leviva kuulujutu kõrvaleheitis, võib tähendada ka seda, et ta pi das vastavat jututüüpi kuulujutuks. Ka distants, millega M. Crusius sõrmusemuistendit võttis, tulenes ilmselt kartusest sattuda mõne rändmuistendi õnge.

Tees. Mitte iga pärimus, mis sisaldas üldlevinud jutumotiive, ei olnud üldlevinud pärimus.

Sõrmusemuistendi kõrvalejätmist või usaldamist rahvamuistendina (gemeine Sage) ei tohi eraldada õpetlaste tavast kritiseerida kõiki lahkarvamusi ebausaldusväärseteväljamõel distena. Pärimuse kõrvalejätmine kinnitas humanistlikust mõtlemisest mõjustatud historiograafia - sageli mitte vähem spekulatii vset ja segast seisukohta ja tõendas autori kriitilisust (Borchardt 1971: 556). Sõrmusemuistend võib seega olla ka õpetlaste looming, mis ringles üksnes Gmündi kõrgklassiga kokkupuutuvate haritud kodanike hulgas. Rahvamuistendi kohustuslik üldtunnus ei oleainult see, et kõik seda teavad, vaid peab ka usutama, et kõik seda teavad ja et seda tunnustatakse (antiikmüütide ol emusest vt Veyne 1987: 59).

Tees. Mitteiga rahvamuistendina esinev pärimus ei ol nud üldiselt, s.t ka alam- ja keskklassi hulgas tuntud.

Seda arusaama saab laiendada ka muule vastavasisulisele allikmaterjalile. Vastates ühele Württembergi hertsogkonnas 1535. aastal läbi viidud küsitl usele konkreetsete kogukondade nimede, päritolu ja vappide kohta - laekunud teated on ideaal ne ajaloopärimuse allikas - ei teadnud Staufide Stammburgi-lähedase Hohenstaufeni turuasula elanikud midagi sellekohanimepäritolust, edastasid aga omapärasepärimuse. Nad väitsid end ol evat "kuul nud vanadelt inimestelt", et kord ol la Hohenstaufenis ja Elisabethenbergil (Waldhauseni lähedal) valitsenud kaks Švaabimaa hertsogit, Konrad ja Heinrich, kellest üks olevat saanud pärast F rankfurdi all peetud lahingut keisriks, teinekuningaks. Detailselt kirjel datakse mõlema isanda vappeenneja pärast ametikõrgendust (Graf 1984: 105; Graf 1987a: 77). 
Kogu lugu võiks pidada üllatavalt sarnaseks 1485.-1486. aastal UImis ilmunud Thomas Lireri koostatud Švaabi maa kroonika episoodiga, selle ümbersõnastuseks või loo üles kirjutanud ametniku seikluslikuks fantaasiaks, kui ei apelleeritaks "vanadele inimesteIe". ${ }^{37}$ Kas siin kehtib Günther Kapfhammeri otsus kohanime-etümoloogiate ja samalaadsete etiol oogiliste muistendite kohta: Tõsielul põhinev suuline pärimus käsitl eb teisi teemasid (Kapfhammer 1980: 46). ${ }^{38}$ Kuid mis on tõsielul põhinev suuline traditsioon? Kas ei oleka niisuguse konstateeringu puhul taas tegemist ühekülgse dieediga, mille raames ketrustubade lood üleloomulikest jõududest kuulutatakse suulisetraditsiooni paradigmaks? On väga või malik, et Hohenstaufeni turuasula talupoegade eneseteadlikul ülemkihil ol id heral dilised ja ajal ool ised huvid ning neid vahendati vestluses, seega suulisel kujul. Sama hästi on võimalik, et tuginemine vanadele inimestele kujutab endast pelgalt tõendusvormelit, mille abil taheti lisada autoriteeti teatud ajaloolisele seisukohale - see on võrrel dav tuginemisega iidsele päritolule, vanale heale tavaõigusele, mis peaks justkui laienema ka uuel e õi gusele.

\section{Romantilised fabrikaadid (ümbertöötlused)}

E espool sõnastatud tihedast seosest ajal ool ise pärimuse ja ajaloolise hariduse, aga ka teiste ajalookultuuri valdkondade vahel on eriti rohkelt tõendeid 19. sajandist. Käsitletud valdkondadele lisandub veel fiktsionaal ne ajalooline jutt (ajalooline ballaad, ajalooline romaan). 1848. aasta märtsirevolutsiooni eel sete aastakümnete (nn Vormärz ${ }^{39}$ ) "Staufi-buumi" (Schreiner 1979: 539) ajal sai Gmündi sõrmusemuistend kui Staufi pärimus ka kirjanduslikemuganduste aineks. 1827. aastal ilmus Gmündi nädalalehe meelelahutuslisas 44-stroofiline bi idermeierliku literaadi J oseph E pple luuleteos Taasleitud abiel usõrmus ehk J ohannesekirik Schwäbisch Gmündis (üks muistend). Selles ja hilisemateski töötlustes - nimetatagu veel 1861. aastal esmatrükis ilmunud ülimenuka naiskirjaniku LuisePichleri vihikukest Hertsoginna sõrmus. J utustus noorteleja rahvale- on muu hulgas äratuntavad järgmised kol m ümbertöötamistendentsi:

1) moraliseerimine ( . E pple püüab esitada näidet voorusest antud juhul naise truudusest);

2) emotsionaliseerimine: tegelaste tundeelu ja nende motiivid tuuakse rõhutatult esile; 
3) koloreerimine: ajaloolise romaani stiilist pärit värvikate detailidega kaunistamine.

Seda, kuidas romantiline rahvaluuleaustus oli sunnitud appi tulema auahne noore autori kirjanduslikule enesekehtestamiskihule, näitab hilisema tuntud kirjaniku, tollal alles 19-aastase J ohannes Scherri švaabi muistendikogumiku Sagen aus Schwabenland ilmumine 1836. aastal.$^{40} \mathrm{~J}$. Scherri sõrmusemuistendi töötlus kujutab endast metsikult liigutavat armastuslugu, mille peategelased kannavad kauneid germaani nimesid Ekart, I rmengard, Horsa ja Hermengild. J uba vähem kui kümne aasta pärast võttis üks õpetatud muistendikoguja J. Scherri versiooni rahvasuust pärit muistendina ja populaarseautori Ottmar Schönhuthi 1860. aastal ilmunud muistendiraamatus DieBurgen, Klöster, Kirchen und Kapellen Württembergs (Württembergi kindlused, kloostrid, kirikud ja kabelid) trükiti J . Scherri töötlus juba tema nimeta - mis on ka mõistetav, sest seda peeti rahvamuistendiks. Tekib kahtlus, et tol lastes rahvamuistendites peegel dusid haritud kodanikkonna enese kaunid mõtted. Seda paljastab pi isavalt fotograaf August Lorenti ilmselgelt - antud juhul keldi laadi - mütoloogiaseenega ${ }^{41}$ nakatatud tõlgendus 1869. aastast pärinevale Gmündi J ohannese kiriku lõunaküljel ristilöömisstseeni kõrval kujutatud patukahetseja figuurile. Ta näeb selles rahvast kui ohvrikoogi ga druii di ning kogu gruppi kokku kui kristlusevõidu sümbol it paganl useüle(L orent 1869: 26).

L iialdatult võiks öelda, et 19. sajandil meel disid rahvamuistendid kooliõpetajatele, pastoritele ja teistele isamaa-austajatel e ning neid vahendati ikka ja jälle, enamasti pedagoogilistel eesmärkidel lihtrahvale. Rudolf Schenda salvav artikkel Mären von deutschen Sagen on selle kohta öel nud mõndagi tabavat (Schenda 1983).

Tees. 19. ja 20. sajandi muistendeid tuleb võtta tõsiselt, kuid eelkõige kirjandusliku nähtusena. Nende (v.a arvukateilmsel gete võltsingute) kirjandusteaduslik liigitamine on esmajärgulisem kui vajadus leida nendest rahva suus liikunud jutte või vana pärimust.

Neli näidet kitsalt piiritletud alalt illustreerigu asjaolu, et muistendite kogumise ning 19. ja 20. sajandi historiseerivate püüdluste kokkupuutepunkte ei tohi jätta märkamata.

(1) Ernst Meieri švaabi muistenditekogumikus ilmus nr 48 all jutt Gmündi viiuldaja, lisamärkus allika kohta: suuliset Gmündist (Meier 1852: 44). Peter Spranger arvab oma metoodiliselt eeskujulikus töös J ustinus Kerneri esmakordselt 1816. aastal ilmunud luuletuse Gmündi viiuldaja eel- ja järellookohta õigustatult, et Meier ei tundnud Kerneri 
ballaadi ja pidas lugu Gmündi viiuldajast vanaksmuistendiks(Spranger 1980: 100). Nostalgiaihalusest paigutab J. Kerneri loodud legend Schwäbisch Gmündi kulla- ja hõbedatöötlemise õitsengu keskaega see on ajalooliselt vettpidamatu kujutelm, mis 19. sajandi esimesest poolest pealeon olnud Gmündi kodukohakirjanduse(Heimatliteratur), ajaloolise romaani ning isegi tänapäevaste reklaamtrükiste ja linna tutvustavate brošüüride aineseks (Graf 1984a). ${ }^{42}$ I sel comulik on korduvalt - ka sõrmusemuistendi kohandustes - esinev Gmündi väärismetallitööstuse projitseerimine Staufide valitsemisaega, seostamine Gmündi Staufide-aegsetraditsiooniga, millesajanditepikkus ja autoriteet lasub kaitsvalt noorel, pärast 1800. aastat käsitöönduse turukriisi aegu romantismi vaimus sündinud kullassepatraditsi oonil. Niisuguste pärimuste oluliseks vahendajaks oli kodulooõpetus. ${ }^{43}$ Veel 1981. aastal mäl etas 1920. aastal sündinud gmündlanna selgelt 1931. aasta kodulootundi, kus käsitleti Staufide ajastu aadliturniire - jutt käis 15. sajandist pealeallikal iselt tõendatavast pärimusest, millejärgi turniiri võitjale ulatas tema autasu, kuldse pokaali, kõige kaunim kullassepatütar (Graf 1984: 112).

(2) Ü hes muististe-teemal isest ülemaal isest küsitlusest ajendatud ja 10. jaanuariga 1837 dateeritud kirjutises, mille Straßdorfi kirikuõpetaja Gottfried Eyth saatis Württembergi ülemametile Gmündis, annab ta teavet Schirenhofi Rooma-aegse kindluse varemetest. Keskaegsest nimetusest E tzelsburg - tunnistus kangelasmuistendite olemasolust - on tõestatavaid andmeid alates 1385. aastast (Graf 1984: 142, 165). ${ }^{44}$ Rahvamuistend, mida si iani on peetud usaldusväärseks pärimuseks, kirjutab pastor G. Eyth, paigutab Hetzel burgi lossi rajamine 2. sajandisse, mil osa J ulius Caesari Rooma leegi onerändas mööda Saksamaa metsi . Kaks Rooma rüütlit ol evat siis otsustanud sinna elama jääda. G. Eyth väidab ka, et ta ol evat 1823. aastal suutnud sel gelt dešifreerida kivisse raiutud sõnad: Haeaedes veterum equitum renovataesunt anno domi ni MLDV, kivi aga olevat seejärel kadunud. Lossi kokkuvarisemisest ei teadvat pärimus midagi, võib aga oletada, et see hävitati nagu palju muudki 1525. aasta talurahvasõjas. Pärast lühikest Iõiku Rooma mündi leidudest jõuab G. Eyth veel ühevana, tõenäolisel t hinnal iste aardeleidudei hal usest tekkinud muistendini , millejärgi maa-alustes käikudes, mis sel lest kunagi sest kindlusest vel järel on, olla peidus erakordselt kallis kullast ja hõbedast lauamäng. Kõik räägib selle poolt, et väidetavalt 1455. aastast pärinev raidkiri oli võltsing, mis pi di toetama Straßdorfi kirikuõpetaja romantiliselt jul get ka- 
vatsust luua ühenduslüli Rooma kindlusteja keskaegsete rüütlilinnuste vahele - seega oleks kogu lugu historiseeriv spekulatsioon, mis leiab aset rahvamuistendi romantilise võlukübara all.

(3) Gmündi ülemõpetaja Georg Stützi raamatu Sagen der Heimat kolmandas trükis (Stütz 1981: 23-28)45 leidubjutt Valerahategija, mis on lisatud ka LuzieStützi vastutusel välja antud teisele, 1950. aastal ilmunud trükile (vt ka Graf 1981). J uba esimesest lausest õhkab ajaIoolise romaani ülespuhutud ja tänapäeval peaaegu seedimatuks muutunud tooni: "Sellest võib olla nelisada aastat, mil riigilinnas Schwäbisch Gmündis asus uhke relvatöökoda." See on jutuelementide osas (otsene kõne, dramaatilised detailid, uute tegelaste lisamine) rikkal ikult täiendatud ümbertöötl us kaastööst, millekauaaegne Gmündi linnaarhivaar Al bert Dei bel eaval das 1933. aastal nooreõpetajana teoses Lühikesed teated Vana-Gmündist. 2. Valerahategija Sperfechter (Gmünder Heimatblätteris pealkirja all Kleine Nachrichten aus Altgmünd. 2. Sperfechter der Falschmünzer). Deibele väidab oma allika kohta: Debleri krooni ka on meileedastanud tõeliselt dramaatiliseloo, millemesi in vabalt ümber jutustame.

A. Deibel e rohkesõnalisele otsese kõnega pikitud jutule valerahategija Sperfechterist, kes tõi raetellimusel eel nevast hoiatusest hoolimata si iski F rankfurdi messilt kaasa uue kohtumõõga ja sel le läbi esimesena surma saadeti, I leiab vaid väga kasinat tuge Bibliotheca Gamundiana komplekteerija Dominikus Debleri kroonikast (vt ka Debler 1985: 90-99), mis valmis pärast 1800. aastat:

Rahavermijast mõõgasepistaja Sperfechter ja tema nainehukati siin. Meest oli ette hoiatatud, temalt oli ka uus mõõk tellitud, mille ta ära tõi. Kuna ta kutsuti rae ette, hoiatasid teda mitmed linnakodanikud, et ta põgeneks ja sinna ei läheks, aga tema ei võtnud neid kuulda ja läks nii isehukatusse. Tema ainuke tütar läks Püha Ludwigi kloostrisse. Nad olid jõukad inimesed.

J uba A. Deibele dateering - 16. sajand - on fiktsioon ja ka valerahategija maja täpneasukoht pärineb mingist teisest allikast, mida pole nimetatud, tõenäol iselt 1835. aastal ajal ehes avaldatud kroonikast.

(4) G. Stützi (1981: 17-19) muistendiraamatus on aval datud jutt Gmündi linnakohtunik, mille kindlalt teadaolev esmatrükk ilmus Württembergi Õpetajakoolituse Abistamise Seltsi välja antud raamatus Württembergi sche Vol ksbücher (Württembergi rahvaraamatud). Historiseerivate üksikasjadega varustatud dramaatiline lugu 
Gmündi linnakohtunikust, kes mõistab 1399. aastal surma oma röövliks hakanud venna, Iõpeb pika värsivormis hauakirjaga, mis ol evat väidetavalt algselt asunud dominikaanlaste kloostri kiriku juures. $\mathrm{Nii}$ muistend kui ka hauakiri on ilmselgelt loodud 19. sajandil. Kurioossel kombel võeti neid aga 1954. aastal ilmunud kodukandikirjaniku Hildegard Meschenmoseri ${ }^{46}$ esseistlikus stiilis Gmündi ajaloo käsitluses (Meschenmoser 1987: 26-28) ometi tõe pähe.

Raamatule Württembergi rahvaraamatud (Württembergische Volksbücher) lähedaneisamaal isteajalool istejuttudekogumik Württemberg wie es war und ist (Württemberg nagu see oli ja on) pidi äratama rahva, eriti noorsoo huvi Württembergi ajaloo vastu. Tõsiasjale, et see sisal dab arvukaid näiteid fiktiivsetest, ebaehtsatest muistenditest, mis pärinevad valdavalt Wilhelm Friedrich Munderi sul est, on taasosutatud all es hiljuti (Trugenberger \& Wieland 1980). ${ }^{47}$

\section{Päritolu ja eksempel}

Sõrmusemuistendi temaatikat kujutaval õlimaalil Gmündi J ohannese kirikus nihutab stseeni kohal pilvedel seisva jumalaema ja kahe pühaJ ohannese kujutis juhtumi religioossesse konteksti. Kas see tõik ei viita sõrmusemuistendi al legoorilisele seletusele? Sõrmus oleks seega truuduse, ustavuse ja usu sümbol. Selles vaimus inter preteeris linna rajamise pärimust ka Donzdorfi dekaan J ohann Georg Schroz 1762. aasta pidulikul jumalateenistusel: "Vundamendiks, millele linn rajati, tundub olevat truudus ja usk." Sõrmuse kaotamine on seega pattulangemine, kiriku ehitamise tõotus märgib tagasipöördumist headuse pool eja lastud hirv, kellesarvist kaotatud sõrmus leiti, on võrrel dav K ristusega, kelle märtrisurm tõi maailmale lunastuse. Seega võiks sõrmusemuistendit pidada tahtlikuks loominguks, kirikliku usuõpetuse eesmärgistatult läbi mõel dud näidiseks ja didakti ku plaani pärasekaalutl emi setulemuseks, kui nõustuda Dietz-Rüdiger Moseri ol etustega, kes on kirjeldanud rahvajuttude val dkonda eel kõige vastur eformatsiooni misjoniordude usupropaganda tandrina (Moser 1977: 72; Moser 1982: 132). Kas sõrmusemuistendi laadi pärimustel on seega selgelt tõestatav kavatsuslik sisu, mille võiks kuulutada niisuguste juttude genuiinseks horisondiks (Moser 1982: 125)?

Seda, et intentsionaalsed ja mentaalsed kontseptsioonid, mis arvavad pärimuste tähenduselähtuvat nendeloojate kavatsustest või 
mentaal setest protsessi dest, on märksa problemaatilisemad kui valitsev teooria nõustub tunnistama, ei ole võimalik siinkohal lähemalt selgitada (lähemalt vt Graf 1987a: 13jj). Kavatsusideekriitika saab tugineda järgmisel eargumendile: kes tahab jutu kinnistada ühe õige, essentsialistliku tähenduse külge, mingi kuulajast sõltumatu sõnumi külge, mis tuleb lahti kodeerida, ei näe seda, et juttudetõeline võlu, mida saab välja lugeda nende pärimusena levimisest ja retseptsioonist, põhineb nendeavatusel erinevatel einter pretatsioonidele. ${ }^{48}$ Essentsialism on kõige ühekülgsem dieet üldse, nagu see nähtus ka ajal oomõiste arutel ust (Demandt 1984: 172 jj). Ü mberlükkamatud väited muistendi kui sellise kohta viivad sama vähe edasi kui strukturalistlikud imevormelid. Sõrmusemuistendi puhul võiks konkreetsetevariantide põhjal vaevata välja sõeluda põhistruktuuri puudus (sõrmusekaotus) - puuduse kõrvaldamine või normi rikkumine- normi kehtestamine, mi da lõpptulemusena saab seletada üldinimliku õnneihalusega. See, kes jutud nende endi vürtsist ilma jätab, ei tohiks üllatuda, kui Iõpuks millelgi enam õiget maitset pole.

Küsimused ajaloolisest tuumast ja algvariandist põhinevad essentsialistlikul kontseptsioonil. Marc Bloch on nimetanud algupära otsimist ajal oolasteebajumalakummardamiseks: J uba vanad etümol oogi d hällitasid ill usiooni, nagu ol eksid nad sel lega kõik öelnud, kui olid mingi sõna käi bel ol evatest tähendustest vanima välja selgitanud [---]: justkui poleksigal sõnal mitteainult tähendus, vaid ka määratud roll kel es (Bloch 1985: 27 jj, 30). Sõrmusemuistend on konstruktsioon, millel pole iseeneslikku, vastavas uurimisseoses pragmaatilisest määratlusest sõltumatut olemust. Kui kasutada ülalnimetatud mõistet perekondlik sarnasus (L. Wittgensteini kasutatud tähenduses), võib sõrmusemuistendit mõista eel kõige variantide kogumina, mida hoiab koos rida ühismotiive, kusjuures iga motiiv ei pea esinema igas variandis.

Perekonnaga võrdlemine näitlikustab ka tõsiasja, et pärimuse puhul ei saa kindlaks teha absoluutset päritolu, nagu ka perekonnal ei saa ol la bioloogilises mõttes üht ajalool iselt identifitseeritavat esiisa - päritolu sõltub valitud identiteedikriteeriumist, s.t valitud motiivikogumist (Graf 1987: 111 jj). Pärimuste puhul ei saa kasutada klassikalise tekstikriitika paradigmat - mehaaniliselt kopeeritud pärimuslike tõenditesugulusahelat. Muistendiuurimused, mis opereerivad arvukate tul etatud algvormidega - mõel dagu kas või nn kangelasmuistenditele - , lähtuvad sageli küsitava väärtusega pärimuse seaduspärasustest ${ }^{49}$ või motiivideal gupärast, nii- 
si is essentsialistlikest argumentidest, milletaga on hõlpsasti tajutav igatsus ajal oolise tuuma või eriliselt väärtusliku esteetilise kvaliteediga algvormi järele.

Perekonna võrdpildi põhjal saab ka selgeks, miks mingit traditsiooni järgitaksenii paljudeaastasadadevältel. Sajandeid konstantsetest pärilikest al getest, mis määravad mingi perekonna ajalooliserol li, tänapäeva geneetikud enam ei räägi. Kuuluvust mingisse perekonda saab piisavalt muutumatu mõjufaktorina arvesse võtta ainult kahe kuni kolmepõlvkonna vältel - isegi kui Habsburgide-sugusedünastia perekondlik teadvus püüab seda ajal ool ist avastust ignoreerida. Perekonnalood võib mittegeneetikutele köitvaks muuta asjaolu, et need liidavad endassekonkreetseteinimesteajaloona paljusid tüüpilisi ajalookogemusi. ${ }^{50}$ Samamoodi avab ka variantide kogumina vaadeldav pärimus õpetlikke seoseid. I ga variandi kontekst ja sisu paigutavad selleteatud diskursusesse, talle omasel etähenduslikuleja žanrilisele taustale (Graf 1987a: 16jj). Kui sõrmusemuistendit käsitl etakseharitlaste töödes, kuulub see õpetlaste diskursusesse; kui sellega tahetakse määratleda linlikku identiteeti, kuulub see linlikku omadiskursusesse, mida esindab 16. ja 19. sajandi Staufi-diskursus.

Tees. Pärimuse muudavad uurimiseks relevantseks ajastuomased diskursusteristumispunktid ühe konkreetse pärimuse variantides, mittekindlakujulise substantsina kõikides kontekstides säiliv pärimuse tuum.

Kas sõrmusemuistend on pigem seotud ajalooga (kui Staufide pärimus) või kohaga (kui J ohannese kiriku tekkemuistend)? Selline varjatud päritoluküsimus, mis tugineb eespool tsiteeritud vendade Grimmide määratlusele, on mõistagi valesti esitatud. Sama kehtib küsimuse kohta, kas sõrmusemuistend on tegelikult, s.t algselt olnud tekkemuistend või vaga eksempel. J ärgnevas püütakse näidata põlvnemiseja eksempli ${ }^{51}$ vastandami sekaudu, millises suunas võiks täpsem mõistemääratlus jutu-uurimises ja tekstoloogias liikuda.

Asjaolule, et mõiste põlvnemine on - esinedes näiteks sellistes varauusaegsetes raamatupeal kirjades nagu ... päritolu ja põl vnemi ne- moodsa ajaloomõiste eelkäija ja seega võtmetermin varasema historiograafilise diskursuse teooriale, on juba viidatud (Graf 1984: 70 jj). Selle sõna tähendused - päritolu, traditsioon, põlvnemine, tava - seovad kriitikaeelsel viisil ajaloolise kogemise võimalused. Üldiselt on põlvnemine määratletav tekstifunktsioonina, mis seob antud loo tema seostamisobjektiga. Selle seostamisobjekti - mingi 
eseme, isiku, rühma või institutsiooni - identiteeti väljendatakse, põhjendatakse, legitimeeritakse või seletatakse põlvnemise abil. Ütlus i dentitedi väljendami neseostub ajal ool ise mõtlemise funktsiooniga, mida põhjal ikult on kirjeldanud Hermann Lübbe: J utustatud lood on oma ja võõra identiteedi väljendamisevahendid (Lübbe 1977: 175, vt ka 168 jj). ${ }^{52}$ Sõrmusemuistend on osa linlikust põlvnemisest, s.t osa riigilinna Schwäbisch Gmündi ajalooliselt, juttude abil loodud eneseteadvusest. Tavapärasel viisil seostataksejutt konkreetse objektiga loo autori, mõne kuulaja või interpreteeriva uurija kaudu. Oleks väär tahta avastada mingit tegelikku põlvnemist, kui jutt ei osuta tekstisiseste signaalide ega ka kasutuskonteksti kaudu objektile, millega seda tul eks seostada. Üks ja sama lugu on käsitel dav kõikide jutus sisalduvate obj ektide põl vnemi sl oona.

Põlvnemine ei määra ainult ühe seostamisobjekti identiteeti, vaid selle abivahendina toimivad jutumotiivid ja vi ited teiste seostamisobjektide põlvnemisele. Gmündi Staufidega seostuv rajamine haakub äratuntavalt mitut piirkonda hõlmava Staufi traditsiooniga. Samalaadne seos, nagu eespool juba näidatud, on 19. sajandi kullassepatraditsioonil Staufi traditsiooniga. ${ }^{53}$ Ü he pärimuseliitmisel teisega (geneal oogilise põl vnemise val dkonnas räägitakse sel listel juhtudel ka sugulustumisest) tuleb siiski ette ka ülepakkumisi. Üheks näiteks sellest on Saksa linnade hiliskeskaegne Trieri pärimus. Pärimuses väidetavast vanimast asustusest Trierist al gusesaanud linnad aktsepteerivad küll oma põlvnemisosadust, kuid sellegipoolest on mõned neist püüdnud end esile tõsta väitega, et nemad ol evat rajatud vahetult pärast Trieri (Graf 1988: 182). ${ }^{54}$ Põlvnemine oli Pierre Bourdieu sõnul sümboolne kapital (vt nt Bourdieu 1982: 127, 359; Graf 1984: 184), millega manipuleeris eelkõige ülemkiht.

Põlvnemise tekstiline funktsioon on kõrvutatav eksempli tekstilise funktsiooniga. See kätkeb jutusse mingi õpetuse või reegli ${ }^{55} \mathrm{Kui}$ jäl gi da ülimalt problemaatilist autori kavatsuslikkusekontseptsi ooni, peaks jutustaja või autor olema teksti peitnud sõnumi, milleinterpreteerija peab üles leidma. Siinkohal esindatav pluralistlik tähenduskäsitlus toonitab seevastu juttude avatust erinevatele tõlgendustele. Pärimuste mitmetähenduslikkus on sageli sel etuseks asjaol ule, miks neid üldsepärimusena edasi antakse. Levinud jutumotiivid polemingid müütilise tõe ega ühese tähenduse kandjad, need on levinud just seetõttu, et neid saab sobitada paljudesse kontekstidesse.

On lihtne mõista, et iga juttu saab vaadel da nii põlvnemisl oo kui ka eksemplina. Seega on sõrmusemuistend J ohannese kiriku põlv- 
nemislugu, aga ka eksempel nii püha tõotuse tulususe kui ka unustamise varjukülgede kohta. Kui mingit lugu võetakse eksempeljutustusena, kahvatub selle seos koha- ja isikunimedega ning need on vajalikud vaid selleks, et juttu tõepärasemaks teha. See vaatenurk või mal dab ümber hinnata nn tekkemuistendid koos neis väljenduva ajal ooga, mis ulatub tänapäeva (Heimpl 1932: 230). ${ }^{56} \mathrm{Kes}$ hoiatab eti oloogiliste sõnakõlksude ülehindamise eest (nt Richter 1971: 58), ei suuda näha objekti ja jutu vahelist sümbiootilist seost. J utustus annab objektile loo, samas aga tagab objekt kui teatud kujutelma pildilinetähis (Daxelmüller 1987: 620) sellelootõepärasuse.

Sama kehtib riituse kohta: seda saab juttude kaudu selgitada või õiguspärastada, samas annab seeaga omakorda juttudele usutavuse. Päritolu- ehk põlvnemislugu on mingi toimingu (mitte alati tõene) asutamisürik (B. Malinowski charter), ${ }^{57}$ mis kuulutab sellekehtivaks. Seda, et tavapärane tekkemuistendite eristamine ajaloolistest pärimusest on mõttetu, näitab sõrmusemuistend, mis on ühtaegu nii isikupärimus kui ka mälestusmärgijutt (Denkmalerzählung). ${ }^{58}$ Ehitised ja objektid, millel on mingi rühma elus eriline koht, tõmbavad vältimatult ligi lugusid ja sunnivad endast jutustama. ${ }^{59}$ Sagel i annab pärimus sel gitusi nn relikti de, ${ }^{60}$ funktsioonituks muutunud ja seega mõistetamatute ol meel ementidekohta, paigutades need levinud jutukompleksidesse, nagu näiteks hiiglase- või paganajuttudesse.

Küsimusele, kas sõrmusemuistend on arenenud hilisromaani stiilis J ohannese kiriku figuuriliste kujutiste sel etusmuistendina või tõlgendatakseneid kujutisi tagantjärelesõrmusemuistendi põhjal, pole võimalik vastata. See on ka täiesti tähtsusetu. Seda, kas sõrmusemuistend on tegelikult põlvnemislugu või mis tahes õpetuse teenistuses olev eksempel, otsustab iga lugeja või kuulaja iga kord uuesti. Tähenduse küsimus, millega vaevavad ennast intentsionalistid ja essentsialistid, langeb ära ja selle asemel e kerkib võimalus individuaal seks tähendusl oomeks ja aval ikuks, dial oogiliseks tähenduste rakendamiseks (Graf 1987a: 16 koos märkusega 38).

Tõlkinud Reet Hiiemäe

Tõl gitud ajakirjast F abula 29 (1988), Ik 21-47, originaal pealkiri Thesen zur Verabschiedung des Begriffs der 'historischen Sage'.

Klaus Grafi publikatsioonevt Interneti aadressidelt http://web.archive.org/ web/19990117054758/http://www.uni-koblenz.de/ graf/sagslg.htmhttp:// web.archive.org/web/20011031051946/http://www.uni-koblenz.de/ graf/ index.html ja http://www.bsz-bw.de/rekla/show.php?mode=source\&id=383 


\section{Kommentaarid}

${ }^{1}$ Klassifikatsiooniprintsiipide kohta vt Röhrich (1976: 51 jj), Grimmide kogumiku domineerimisest vt Uther (1986: 19-27).

2 Toetudes rahvaluulealastele töödele (vt Graf 1987: 123) võiks vaagida muistendi ja ajal ool isepäri muse puhul esilekerkivaid lahkarvamusi müüdistumise mõiste osas (nt Bartesi suhteliselt ebaselgete mõttearenduste põhjal (Barthes 1981; Petzoldt 1984)). Minu arvates toob efektse mõiste müüt kasutamine arutelusse tarbetut ebasel gust - tõhusam selgitus, mida ei saa siinkohal ruumipuudusel esitada, peaks lähtuma K. Hübneri fil osoofilises mõttes määrava tähtsusega uurimusest (Hübner 1985) ja võiks hõlmata ka arutluse libahundimuistendist ajakirjas Zeitschrift für Volkskunde 82 (1986), Ik 189-226). Hübneri substantsialistlik fiktsioon kõikides kontekstides läbivalt esinevast müütilisusest ei kehti levikuprotsesse puudutavate küsimuste puhul. Siin tuleks arutlust müüdistumise protsessi üle arendada kahes suunas: 1) kui faktilise muutumist muistendiliseks (selle klišee kriitika kohta vt märkus 23 ja Neureuter 1984); 2) kui mingi pärimuse muutumist või redaktsiooni. Selleks, et rahuldavalt toime tulla teise punktiga, oleks kindlasti vajalik eel nev interdistsiplinaarne kokkulepe analüüsitendentside terminoloogia ja tüüpide asjus (vrd nt Gieri nõuet anda edasi kõnesoleva jutuainese konkreetseesi tamisetehnika (Gier 1977: 197; vt ka märkus 43).

${ }^{3}$ Vt kõige uuematest H. Bausinger ajakirjas Fabula 26 (1985), Ik 173-175 ja Bausinger 1984 (kirjanduse loend).

${ }^{4}$ Seda eristust toonitas juba 1929. aastal R. J akobson (1979: 140-157), vt ka A. Assmann (1983).

${ }^{5}$ Ajal oo- ja kirjandusteaduse integreerimisest teatava diskursusel oo sildi all vt Graf (1987a: 228-231).

${ }^{6}$ Kriitilist diskussiooni nende kahe mõiste kohta vt K. Graf (1987: 121 jj); funktsiooni kohta J . L. Fischer (1987) ja L. Honko (1987).

${ }^{7} \mathrm{~F}$. Lanzoni (1925: 2) defineerib leggendat: un racconto fantastico, inquadrato in luoghi o in tempi storici, o coll legato con un personaggio, con un tempo o con un luogho appartinenti alla storia.

${ }^{8}$ Vt M. Blochi (1985: 73-86) vastavateemalist arutlust.

9 Vähemalt ära märkida tul eks ka kangelasmuistendi uurimisega seotud vanema perioodiga tegeleva germanistika uusimad jõupingutused (vrd Heinzle 1987: $19 \mathrm{jj}$ ).

${ }^{10}$ Eriti üksikasjaliselt välja arendatud ja hiliskeskajani tagasi ulatuva Staufi traditsiooni (Graf 1984: 17-32, 103-122) kõrval vaadel dakse ametlikku traditsiooniharrastust, nagu see avaldub näiteks ühes linnapeade 


\section{Klaus Graf}

nimekirjas ja linna ajalooraamatu kroonikas (Graf 1984: 123-130), kodanlike, kuid oma aadellikku päritolu tõestada püüdvate perekondade pärimust (Graf 1984: 131-143) ja Gmündi kloostri rajamise lugusid kui püüet määratleda vastava ühisomandi seisundit (Graf 1984: 144-156). J ärgmine alaosa "Veel ajaloolisi pärimusi ja rahva ajaloonägemusest" (Graf 1984: 157-170) käsitleb Gmündi kolmekuningatraditsiooni (1164. aastal olevat siin paiknenud pühakute säilmed), Gmündi sõrmusemuistendit, Näbersteini ja Sankt Salvatori kaljulõhangutega seotud pärimusi (paganate eluasemed, maa-alune käik) ning linlike eripäradega seletusmuistendeid.

${ }^{11}$ Staufid (Hohenstaufenid), Saksa aadlidünastia. Olid 1079-1268 Švaabimaa hertsogid, 1138-1254 Saksa-Rooma riigi keisrid ja Saksa kuningad, 1194-1268 Sitsiilia kuningad. Tähtsaimad esindajad Friedrich I Barbarossa (1152-1190) ja Friedrich II (1212-1250) (toim).

12 Olen võtnud seisukoha al gvariandi (Graf 1987: 111-113), ajal ool isetuuma (Graf 1987: 113-116), ajalool isemuistendi kriitika (Graf 1987: 119jj), mõistete kandja ja funktsioon (Graf 1987: 121-123) ning päritolu ja eksempli, etioloogia ja tõestatavuse suhtes (Graf 1987: 123-125). U urimus Iõpeb üleskutsega interdistsi plinaarselejutu-uurimisele (Graf 1987: 125). Niisugune üleskutse leidub ka T. Karsti (1984) metoodiliselt ja temaatiliselt lähedases uurimuses ühe Neustadti linnamuistendi kohta.

13 Švaabimaa hertsog Friedrich I (1050-1105; Friedrich I Barbarossa vanaisa), kes ehitas 1079. aastal Hohenstaufenile kindluse, mille järgi hakati Büreni suguvõsa Stauffideks (Hohenstaufideks) nimetama (toim).

${ }^{14}$ Agnes von Franken (von Weiblingen) (1072/1074-1143) oli Rooma keisri Heinrich IV von Frankeni (1050-1106) tütar, hertsog Friedrich I abikaasa (toim).

${ }^{15}$ H. Schliemanni kui võltsija kohta vt W. M. Calder (1986), väidetava Niebel ungi muistendi šifreerimise kohta vt J . J anota ja J . Kühnel (1985), reaalsusele vihjamise probleemist kirjanduslikes tekstides vt viiteid K. Graf (1987a: 88).

16 Näiteks Öhemi Reichenauer Reichschronik (Blaschitz 1983: 116).

17 Vrd näiteks Ladislaus Sunthaimi reisikirjeldust Ülem-Saksamaalt (Stuttgardi maakonna raamatukogu, Cod. hist. fol. 250, fol. 36): Gienngen ain reichstat darinn ain burgkh dor inn ist vorzeittnn ain kunig gesessen (Giengen, riigilinn, kus [on] kindlus, mis oli ammustel aegadel kuninga residents) (allika kohta vrd Graf 1984: $28 \mathrm{jj}$ ).

${ }_{18}$ Paikapidamatu on kõige erinevamate fenomenide koondamine mõiste rahvapärane ajalooteadvus alla sama autori töös teises kirjutises (vt Marchal 1987). 
19 Rahvapärase ajaloonägemuse kontseptsiooni kohta vt K. Grafi (1984: 157) viiteid Dünningeri, Bausingeri, Prüttingi, Sauermanni jt töödele, vt kirjandust ka T. Karst (1984: 27) ja K. Grafi (1984: 169 jj): resümeerivat tähelepanekut Küsimus rahva ajal oonägemusest tunneb esmajoones huvi tema maailmapildi vastu ja on seega valesti esitatud. Kuni polesuudetud pakkuda suul iseajal oo mõiste teoreeti lises mõttes rahul davat rekonstruktsiooni - ning se peaks hõl mama suulisi juttenendekoguulatuses - , ollakse sunnitud uurimisel pi irduma ajal ooteadmistega. Sobivam ol eks siin ol nud kasutada mitmust: vajalikud oleksid erinevad ajaloomõisted suuliselt määratletud kultuurisegmentide kohta.

${ }^{20}$ Sugulasmõiste Historie ajal oo kohta vt Knape (1984).

${ }^{21} \mathrm{~J}$. Rüsen määratleb historiograafiat kui kõike seda, mida või b vaadel da ini mesel ekui lii gi ol endil eomase või mena historiograafilisel t transformeerida monoteeti lisi teadmisi möödunu kohta ajal ooteadvuseaval dumise polüteetiliseks protsessiks.

22 Tüüpiline on J . Kümmelli (1984) pealkirja sõnastus: Erinnern und Vergessen in der Stadt (Mäletamine ja unustaminelinnas). Mäletamise metafoor puudub kahjuks A. Demandtil (1978: 43).

23 Üks selline näide vt K. Graf (1984: 124).

${ }^{24}$ L. Wittgenstein (1977: nr 593): Üks filosoofiliste hai guste peapõhjusi ühekülgnedieet: mõtlemist toidetakseainult üht lii ki näidetega.

${ }^{25}$ Rahvapärimuse seisukohalt on sellele fenomenile tähelepanu juhtinud K. S. K ramer (1957: 212 jj). Ajaloolise poole pealt väärivad nimetamist A. Esch (1984), L. Schnurrer (1983), hiljem ka H. Chlopocka (1987).

${ }^{26}$ Siin ei peatuta pikemalt asjaolul, et küsimusi, mis puudutavad keeleliste väljenduste suhet tegelikkusega, ei saa lahendada ei füsi kalistlikult ega ekslemisega võimalikes maailmades (vrd Runggaldier 1985) ega ka intentsionaalsuse kontseptsiooniga (vt Quine 1980: 381, 331 jj), vaid parimal juhul - skeptilise probleemi pragmaatilise lahendusena (vt Stegmüller 1986) - kindlaksjäämisega nimetatud suhte avatud ja dial oogilisele olemusele.

27 Selle mõiste kohta seoses keskajaga vt B. Guenée (1980: 300-331).

${ }^{28}$ Kirjandusviiteid vt E. J . Nikitsch (1985: 113 koos märkusega 84).

29 Toetusin siinkohal artiklile "Schlachtengedenken in der Stadt" (Graf 1989a); vt ka K. Graf (1987: 120); ajal ool iste mälestuste vahendajate kohta vt kokkuvõtvalt F. Graus (1987: 35-37), kus on vaadel dud ka lahingumälestuspäevi (Graus 1987: 16, märkus 16).

30 Mõiste kohta vt K. Graf (1987: 21).

${ }^{31}$ Lüneburgi vürstiriik rajati Welfide (9. sajandist tuntud Baieri päritol u Saksa vürstisuguvõsa, kes ol i aastail 1209-1218 Saksa-Rooma keis- 
ritoolil) päranduse jagamisel 1267. aastal. 1371. aastal ründasid Lüneburgi kodanikud nende Kalkbergil asuvat kindlust, purustasid selle ja sundisid hertsog Magnuse põgenema. Kuid nende katse linn tagasi vallutada kukkus läbi. Äkkrünnak 1371. aasta 21. oktoobri ööl , nn Ursulaöö, oli aga edukas. Seejärel viidi hertsogi residents üle Cellesse. J ärgnevatel aastatel olid hertsogid sunnitud Lüneburgi õigusi veel gi suurendama (toim).

32 R. H. Lutzi monograafia (Lutz 1979) on liialt kinni antud mõiste kui reaalse rühma kirjel duse realistl ikus interpreteerimises. Sama võib märgata mõningates reformatsiooniajalugu käsitlevates töödes, milles räägitakse lihtinimese (gemeiner Mann) reformatsioonist; vt ka Laube (1978).

${ }^{33}$ Asjakohaseid viiteid poliitilise korra mudelite perspektiivist auf Landsebenevt K. Graf (1987: 100-102; 1988).

${ }^{34}$ Teadmiseks tuleks võtta ka M. Baueri koostatud mõisteajalooline materjal (Bauer 1981).

$35 \mathrm{Nn}$ kroonikajutustuse problemaatika kohta vt W. Brückner (1981). I.-M. Greverus (1968) piirdub iseloomulikult demonoloogiliste muistenditega.

${ }^{36} \mathrm{~J}$ uhin tähel epanu sellele olulisele, sageli kahesilma vahele jäetud uurimusele, mis kujutab endast teadusringkondade arvates F. Grausi (1975) töö täi endust. Võrdlevalt tuleks arvesse võtta P. Veyne tähelepanekuid antiikõpetlaste suhtumisest müüti ning nende kõikumisse kõige imekspandava eitamiseja veendumusevahe, et legendides peitub si iski tõenetuum (Veyne 1987: 73).

${ }^{37}$ Niisuguste appelleerimiste kohta vt L. Zehnder (1976: 23 jj).

${ }^{38}$ Samavõrra vasturääkivusi välistavalt L. Röhrichi (1976: 17) artiklis: muistendid sõnastavad inimese pessimistlikku maail mavaadet.

${ }^{39}$ Vormärz, kirjanduslik Vormärz - kasutatakse üldmõistena valdavalt märtsirevolutsiooni eelsetel aastatel, ajavahemikus 1830-1850 silmatorkavalt poliitilistel eesmärkidel kirjutatud kirjanduse kohta analoogselt poliitilise terminiga. Seondub kirjandusliku rühmitusega N oor-Saksamaa (tähtsamad esindajad Heinrich Heine, Karl Gutzkow, Heinrich Laube, Ludolf Wienbarg, Theodor Mundt jt).

${ }^{40}$ Seda mugandusvormi võiks T. Verweyeni ja G. Wittigi (1982: 219 jj) kombel nimetada kontrafaktuuriks, sest see kasutab ära oma eeskuju kommunikatiivse potentsiaali (muistendite kui rahva poeesia autoriteedi) (Verweyen \& Wittig 1982: 222); vt ka samade autorite teost Die Kontrafaktur (Verweyen \& Wittig 1987: 75).

${ }^{41}$ Rudolf Schenda (1983: 37) väljend. 
42 Nördinud reaktsioone sellele kirjutisele vt nt Einhorn-J ahrbuch 1984. Schwäbisch Gmünd, Ik 172-181; Einhorn-J ahrbuch 1987. Schwäbisch Gmünd, Ik 96.

${ }^{43}$ Kooliõpetuse kui muistendite allika kohta vt P. Assion (1972: 72).

${ }^{44}$ Kõnealuse kirjutiseäratrükki ja sel leteemalist arutelu vt K. Graf (1979).

45 Ühes oma varasemas töös (Graf 1984: 92-95) olen toonud peamiselt trükitud allikatest koostatud muistendikogumiku allikaviiteid. G. Stützi muistendite stiili kohta vt ka Bausinger (21980: 191).

46 Tema kohta vt Rems-Zeitung 14.01.1983.

47 Ühest Munderi jutust ja selle vahendamisest kodulootunnis vt O. Kies (1984).

${ }^{48}$ Filosoofilisest vaatevinklist vt $\mathrm{O}$. Marquard (1981: $90 \mathrm{jj}$ ), tähendusprobleemi kohta ka L. Röhrich (1985).

49 Kriitikat vt M. Blochi (1985: 91 jj) ja K. Grafi (1987: 162) märkustest.

${ }^{50}$ Näitlik on H. Heimpeli (1982) Venerite monograafia, mis järgib ühe perekonna ajaloo põhjal haritud ametnikkonna kujunemist ajavahemikus 1350-1450 ja loob Viini käsikirjade põhjal mitmetahulise panoraami tolle aja poliitilistest ja intellektuaalsetest suundumustest.

${ }^{51}$ Vt järgneva kohta põhjalikumalt kirjutise autori asjakohaseid uurimusi (Graf 1987: 124; 1989).

52 J . Rüseni teooriakavandis on sell ega võrrel dav funktsioonitüüp traditsi onaal ne historiograafia: Niisugused jutud kujutavad järjepidevust põlvnemise kestmisena (Rüsen 1986: 44).

53 Liitumise kohta vt nt Graf (1984: 73, 148) või Cobet (1983: 55): “Rooma endakonstrueeritud varasele ajal oole on omane selle rafineeritud haakimine kreeka muistenditraditsiooni külge."Võrrelda võiks ka tsükliloomisekirjanduslikku fenomeni (näiteks kangelasmuistendi valdkonnas) ning mõistet muistendiring.

${ }^{54}$ Antiikkreeka paralleelide kohta vt P. Veyne (1987: 99).

${ }^{55}$ Rahvapäraste eksemplite uurimise kohta kokkuvõtvalt vt C. Daxelmüller (1984; 1986).

${ }^{56}$ Lähedane on etümol oogi line põlvnemine, mingi jutu või omaduse tuletamine selle nimest, vrd A. Brückner (1984) ja K. Graf (1984: 111, 169).

${ }^{57}$ B. Malinowski mõiste charter kohta vt G. S. Kirk (1980: 31, 57 jj).

58 L. Röhrich (1981: 424) pakub välja mõiste ikoonilinemuistend.

59 Vt nt J ohannese kiriku kohta (Graf 1987: 95 jj), Gmündi majade kohta käivatest muistenditest (Graf 1984: 168), Ulmi toomkiriku kohta (Mauch 1873).

${ }^{60}$ Relikte saab sel etada ainult loo jutustamise abil (Lübbe 1977: 94 jj). 
Klaus Graf

\section{Kasutatud kirjandus}

Assion, P. 1972. WeißeSchwarzeF eurige Karlsruhe.

Assmann, A. 1983. SchriftlicheF ol klore. Schrift und Gedächtnis. München, Ik 175-193.

Bartes, R. 1981. Mythen des Alltags. Frankfurt am Main.

Bauer, M. 1981. Die“gemain sag" i m späteren Mittelalter. Diss. Erlangen \& Nürnberg.

Bausinger, H. ${ }^{21980 . ~ F o r m e n ~ d e r ~ V o l ~ k s p o e s i e ~ B e r l i n . ~}$

Bausinger. H. 1984. Erzählforschung. K. Ranke et al. (toim). Enzyklopädie des Märchens IV. Berlin \& New York, Ik 342-348.

Blaschitz, G. 1983. Eine“DeutscheChronik”. Diss. Wien.

Bloch, M. 1985. Apologieder Geschichte. München.

Borchardt, F. L. 1971. German Anti quity in RenaissanceMyth. Baltimore \& London.

Bourdieu, P. 1982. Diefeinen Unterschi ede. Frankfurt am Main.

Brückner, W. 1979. Narrativistik. Fabula 20, Ik 18-33.

Brückner, W. 1981. Chronikliteratur. K. Ranke et al. (toim). Enzyckl pädie des Märchens III. Berlin \& New York, Ik 1-17.

Brückner, A. 1984 Etymologie. Chronikliteratur. K. Ranke et al. (toim). Enzyklopädiedes Märchens IV. Berlin \& N ew York, Ik 519-527.

Brückner, W. 1985. Begriff und Theorie von Volkskultur für das 17. J ahrhundert. Brückner et al. (toim). Literatur und Volk im 17. J ahrhundert. Wiesbaden, Ik 3-21.

Calder, W. M. 1986. Heinrich Schliemann. J ournal für Geschichtel, Ik 14-25. Chlopocka, H. 1987. Chronikalische Berichte in der Dokumentierung der Prozesse zwischen Polen und dem Deutschen Orden. H. Patze (toim). Geschichtsschreibung und Geschichtsbewußtsein im späten Mittelalter. Sigmaringen, Ik 471-481.

Cobet, J . 1983. Gab es den trojanischen Krieg? AntikeWelt XIV: 4, Ik 39-58.

Davis, N. Z. 1984. Spruchweisheiten und populäre Irrlehren. R. van Dülmen \& N. Schindler (toim). Volkskultur. Frankfurt am Main, lk 78-116.

Daxelmüller, C. 1984. Exemplum. K. Rankeet al. (toim). Enzyklopädiedes Märchens IV. Berlin \& New York, Ik 627-649.

Daxelmüller, C. 1986. Quod non Hamelensi modo an fabula an historia. N. Humburg (toim). Geschichte und Geschichte. Erzählforschertagung in Hameln, Oktober 1984. Hildesheim, Ik 103-111. 
Daxelmüller, C. 1987. Fußspuren. K. Ranke et al . (toim). Enzykl opädiedes Märchens V. Berlin \& New York, Ik 610-622.

Debler, W. 1985. Das Geschlecht der Debler. Schwäbisch Gmünd.

Dégh, L. 1984. Erzählen, Erzähler. K. Rankeet al. (toim). Enzyklopädiedes Märchens IV. Berlin \& New York, Ik 315-342.

Demandt, A. 1978. Metaphern für Geschichte München.

Demandt, A. 1984. Der Fall Roms. München.

Dinzel bacher, P. \& Mück, H.-D. (toi m) 1987. Vol kskultur des europäischen Spätmittelalters. Stuttgart.

Esch, A. 1984. Zeitalter und Menschenalter. HistorischeZeitschrift 239, Ik 309-351.

Fischer, J . L. 1987. Funktion. K. Ranke et al. (toim). Enzyklopädie des Märchens V. Berlin \& New York, Ik 543-560.

Gerndt, H. 1980. Das Nachleben Heinrichs des Löwen in der Sage. W.-D. M ohrmann (toim). Heinrich der Löwe. Göttingen, Ik 440-465.

Gerndt, H. 1986. Volkssagen. U. J eggle et al. (toim). Volkskultur in der Moderne. Reinbek bei Hamburg, Ik 397-409.

Gier, A. 1977. Der Sünder als Beispiel. Zur Gestalt und Funktion hagiographischer Gebrauchstexte anhand der Theophilusl egende. Frankfurt am Main.

Graf, K. 1979. Etzelsburg oder römisches Lager. Rems-Zei tung 26. Oct.

Graf, K. 1981. Vom Falschmünzer Sperfechter. Rems-Zeitung 24. Detz.

Graf, K. 1982. Die Gmünder Ringssage. Einhorn-J ahrbuch. Schwäbisch Gmünd, Ik 129-150.

Graf, K. 1984. Gmünder Chroniken im 16. J ahrhundert. Schwäbisch Gmünd.

Graf, K. 1984a. Die Gmünder Goldschmiedtradition. Einhorn-J ahrbuch. Schwäbisch Gmünd, Ik 156-169.

Graf, K. 1987. Der Ring der Herzogin. Babenberger und Staufer. Schriften zur staufischen Geschichte und Kunst 9. Göppingen.

Graf, K. 1987a. ExemplarischeGeschichten. Thomas Lirers "Schwäbische Chronik" und die "Gmünder Kaiserchronik". München.

Graf, K. 1988. Aspekte zum Regionalismus in Schwaben und am Oberrhein im Spätmittelalter. OberrheinischeStudien 7, Ik 165-192.

Graf, K. 1989. Geneal ogisches Herkommen bei Konrad von Würzburg und im 'Friedrich von Schwaben'. J ahrbuch der Oswald-von-WolkensteinGesel Ischaft 5, Ik 285-295. 
Graf, K. 1989a. Schlachtengedenken in der Stadt. DieStadt im Krieg. Die Stadt in der Geschichte 15. Sigmaringen, Ik 83-104.

Graus, F. 1965. Volk, Herrscher und Heiliger im Reich der Merowinger. Prag 1965.

Graus, F. 1969. Die Herrschersagen des Mittelalters als Geschichtsquelle. Archiv für Kulturgeschichte51, Ik 65-93.

Graus, F. 1975. LebendigeVergangenheit. Köln \& Wien.

Graus, F. 1987. Funktionen der spätmittelalterlichen Geschichtsschreibung. H. Patze (toim). Geschichtsschrei bung und Geschichtsbewußtsein im späten Mittelalter. Sigmaringen, Ik 11-55.

Greverus, I.-M. 1968. Die Cronikerzählung. Vol ksüberl ieferung. Festschrift K. Ranke. Göttingen, Ik 37-80.

Grimm 1981. Vendade Grimmide eessõna raamatule Deutsche Sagen. Darmstadt, Ik 7.

Grundmann, H. 1978. Ausgewähl teAufsätze3. Stuttgart.

Guenée, B. 1980. Histoi reet culturehistoriquedans l'occi dent médiéval. Paris. Gumbrecht, H. U. 1986. Der Vorgriff: Historiographie - metahistorisch? Grundriss der Romanischen Literaturen des Mittel al ters 11/1. Heidel berg, Ik 32-39.

Guth, K. 1984. "Volk" im Verständnis von Theologie und Kulturwissenschaften. Archiv für Liturgi ewissenschaft 26, Ik 38-47.

Heimpel, H. 1932. Dietrich von Niem. Münster.

Heimpel, H. 1982. Die Vener von Gmünd und Straßburg 1162-1447. Göttingen.

Heinzle, J . 1987. Das Nibelungenlied. München \& Zürich.

Honko, L. 1987. Funktionalismus. K. Ranke et al. (toim). E nzyklopädiedes Märchens V. Berlin \& N ew York, Ik 560-568.

Hübner, K. 1985. DieWahrheit des Mythos. München.

J akobson, R. 1979. Poetik. Frankfurt am Main.

J anota, J . \& Kühnel, J . 1985. U ns ist in niuwen maeren wunders vil geseit. Soester Zeitschrift 97, Ik 13-25.

Kapfhammer, G. 1980. Ortsname und Sage. Blätter für oberdeutsche Namenforschung 17 , Ik 29-46.

Karst. T. 1984. Mittelalterlich-neuzeitliche Herrschaft und Verwaltung im Spiegel volkstümlicher Überlieferungen und späterer Reisebeschreibungen. Regionale Amts- und Verwaltungsstrukturen im rhein-hessischpfälzischen Raum. Stuttgart, Ik 1-29.

Kies, O. 1984. Der “Stier von I Isfeld". Zeitschrift des Zabergäuvereins, Ik 68-74. 
Kirk, G. S. 1980. GriechischeMythen. Berlin.

Kleinschmidt, E. 1982. Stadt und Literatur in der frühen Neuzeit. Köln \& Wien.

K nape, J . 1984. 'Historie' in Mittelalter und früher Neuzeit. Baden-Baden. Koch, K. ${ }^{31974 . ~ W a s ~ i s t ~ F o r m g e s c h i c h t e ? ~ N ~ e u k i r c h e n ~ \& ~ V l u y n . ~}$

Koselleck, R. 1979. VergangeneZukunft. Frankfurt am Main.

Kramer, K. S. 1957. Bauern und Bürger im nachmittelalterlichen Franken. Würzburg.

Kümmell, J . 1984. Erinnern und Vergessen in der Stadt. Saeculum 35, Ik 225-245.

Lanzoni, F. 1925. Genesi, svol gimento e tramonto delle leggende storiche. Studi etesti 43. Roma.

Laube, A. 1978. Bemerkungen zur These von der "Revolution des gemeinen Mannes". Zeitschrift für Geschichtswissenschaft 26, Ik 607-614.

Lorent, A. 1869. Denkmaledes Mittelalters III : 4. Mannheim.

Lotter, F. 1976. Severinus von Noricum. Stuttgart.

Lotter, F. 1979. Methodisches zur Gewinnung historischer Erkenntnisse aus hagiographischen Quellen. HistorischeZeitschrift 229, Ik 298-356.

Lutz, R. H. 1979. Wer war der gemeineMann? München \& Wien.

Lübbe, H. 1977. Geschichtsbegriff und Geschichtsinteresse Basel \& Stuttgart.

Marchal, G. P. 1984. Das Meisterli von Emmenbrücke oder: Vom Aussagewert mündlicher Überlieferung. Schweizerische Zeitschrift für Geschichte34, Ik 521-539.

Marchal, G. P. 1987. Die Antwort der Bauern. H. Patze (toim). Geschichtsschreibung und Geschichtsbewußtsein im späten Mittelalter. Sigmaringen, Ik 763-795.

Marquard, O. 1981. Abschied vom Prinzi piellen. Stuttgart.

Mauch, E. 1873. Münster-Sagen. Verhandlungen des Vereins für Kunst und Alterthum in UIm und Oberschwaben 5, Ik 19-24.

Maurer, H. 1984. Sagen um Karl III I Institutionen, Kultur und Gesel Ischaft im Mittelalter. Festschrift J. Fleckenstein. Sigmaringen, Ik 93-99.

Meier, C. 1980. DieEntstehung des Politischen bei den Griechen. Frankfurt am Main.

Meier, E. 1852. DeutscheSagen, Sitten und Gebräucheaus Schwaben. Stuttgart. Meschenmoser, H. 1987. I m Zei chen des Einhorn. Schwäbisch Gmünd.

Moser, D.-R. 1977. DieTannhäuser-Legende. Berlin \& New York. 
Moser, D.-R. 1982. Exempel - Paraphrase - Märchen. E. Hinrichs \& G. Wiegelmann (toim). Sozialer und kultureller Wandel in der ländlichen Welt des 18. J ahrhunderts. Wolfenbüttel, Ik 117-148.

Moser-Rath, E. 1973. Gedanken zur historischen Erzählforschung. Zeitschrift für Volkskunde69, Ik 61-81.

Müller, H. P. \& Köster, H. 1983. Formgeschichte. Theologische Realenzykl opädie 11, G. Krause \& G. Müller et al (toim). Berlin \& New York, Ik 271-299.

Müller, J. D. 1985. Volksbuch/Prosaroman im 15./16. J ahrhundert. Internationales Archiv für Sozial geschichteder deutschen Literatur, Sonderheft 1, Ik 1-128.

Neureuter, H. P. 1984. F aktizität. K. Rankeet al. (toim). Enzyklopädiedes Märchens IV. Berlin \& N ew York, Ik 802-806.

Nikitsch, E.J . 1985. Dionysius Dreytwein. Esslinger Studien 24, Ik 1-210.

Petzoldt, L. 1976. HistorischeSagen I. München.

Petzoldt, L. 1984. Die Geburt des Mythos aus dem Geist des Irrationalismus. Antiker Mythos in unseren Märchen. Kassel, Ik 138-148.

Psaar, W. \& Klein, M. 1980. Sage und Sachbuch. Beziehung, Funktion, I nformati onswerte, Didaktik. Paderborn \& München \& Wien \& Zürich.

Quine, W. V. O. 1980. Wort und Gegenstand. Stuttgart.

Richter, W. 1971. Exegeseals Literaturwissenschaft. Göttingen.

Runggaldier, E. 1985. Zeichen und Bezeichnetes. Berlin \& New York.

Röhrich, L. 1976. Sageund Märchen. Erzählforschung heute. Freiburg.

Röhrich, L. 1981. Denkmalerzählungen. K. Rankeet al. (toim). Enzyklopädie des Märchens III. Berlin \& New York, Ik 421-427.

Röhrich, L. 1985. Zur Deutung und Be-Deutung von Folklore-Texten. Fabula 26, Ik 3-28.

Rüsen, J . 1986. Annäherung: F unktionstypologie der historiographischen Narration. Grundriss der Romanischen Literaturen des Mittelalters 11/1. Heidel berg, Ik 40-49.

Schenda, R. 1983. Mären von deutschen Sagen. Geschichteund Gesel Ischaft 9, Ik 26-48.

Schlieben-Lange, B. 1983. Traditionen des Sprechens. Elemente einer Sprachgeschichtsschrei bung. Stuttgart et al.

Schnurrer, L. 1983. Zeugenverhörsprotokolleals Quellezur Kultur-, Landes-, Orts- und Familiengeschichte. Erlanger Bausteine zur fränkischen Heimatforschung 30, Ik 57-74. 
Schott, R. 1968. Das Geschichtsbewußtsein schriftloser Völ ker. Archiv für Begriffsgeschichte12, Ik 166-205.

Schreiner, K. 1975. Hildegardis regina. Archiv für Kulturgeschichte57, Ik 1-70. Schreiner, K. 1977. Die Staufer in Sage, Legende und Prophetie. DieZeit der Staufer 3. Stuttgart, Ik 249-262.

Schreiner, K. 1979. Friedrich Barbarossa. DieZeit der Staufer 5. Stuttgart, Ik 521-579.

Schreiner, K. 1986. Vom geschichtlichen Ereignis zum historischen Exempel. P. Wapnewski (toim). Mittelalter-Rezeption. Stuttgart, Ik 145-176.

Schubert, E. 1975. "bauerngeschrey". Zum Problem der öffentlichen Meinung im spätmittelalterlichen Franken. J ahrbuch für fränkische Landesforschung 34/35, Ik 883-907.

Spranger, P. 1980. Der Geiger von Gmünd. Schwäbisch Gmünd.

Stegmüller, W. 1986. Kripkes Deutung der Spätphilosophie Wittgesteins. Stuttgart.

Stütz, G. ${ }^{3} 1981$. Sagen der Heimat. Schwäbisch Gmünd 1981.

Zehnder, L. 1976. Volkskundl iches in der älteren schweizeri schen Chronistik. Basel.

Theißen, W. 1974. UrchristlicheWundergeschichten. Gütersloh.

Tremp-Utz, K. 1986. Gedächtnis und Stand. SchweizerischeZei tschrift für Geschichte36, Ik 157-203.

Trugenberger, V. \& Wieland, G. 1980. HistorischeErläuterungen. F. G. Brustgi (toim). Württemberg wiees war und ist. Stuttgart, Ik 251-287.

Uther, H.-J . 1986. Die Rattenfängersage und die Brüder Grimm. Humburg, N. (toim). Geschichten und Geschichte Erzähl forschertagung in Hamen, Oktober 1984. Hildesheim, Ik 19-27.

Verweyen, T. \& Wittig, G. 1982. Parodie, Palinodie, Kontradiktio, Kontrafaktur. R. Lachmann (toim). Dial ogizität. M ünchen, Ik 202-236.

Verweyen, T. \& Wittig, G. 1987. DieKontrafaktur. Konstanz.

Veyne, P. 1987. Glaubten dieGriechen an ihreMythen? Frankfurt am Main. Wittgenstein, L. 1977. PhilosophischeU ntersuchungen. Frankfurt am Main. Wollmershäuser, F. R. 1977. Blätter für Familien- und Wappenkunde 15, Ik 352 (ülestunnistuse protokoll 1471). 